\title{
RECOVERING A MISSING VOICE FROM MUGHAL INDIA: THE IMPERIAL DISCOURSE OF JAHĀNGĪR (R. 1605-1627) IN HIS MEMOIRS
}

BY

\author{
CORINNE LEFÈVRE*
}

\section{Abstract}

This article argues against the common view according to which the Mughal emperor Jahāngīr was a political lightweight who was dominated by his famous spouse Nūr Jahān. Beginning with a discussion of the historiographical processes which presided over the construction of such a negative image, the essay continues with a thorough re-examination of the emperor's memoirs entitled Jahāngìr Näma. This text brings out a coherent and original political voice, in which Jahāngìr skilfully connects his identities of sovereign, naturalist, and collector. The conclusion evaluates the impact of this discourse through a brief analysis of the reaction of the Mughal political and religious elite.

Cet article s'élève contre l'opinion commune suivant laquelle l'empereur moghol Jahāngīr fut une figure politique mineure, dominée par sa célèbre épouse Nūr Jahān. Il s'ouvre sur une discussion des processus historiographiques qui présidèrent à la construction de cette image négative, et se poursuit par une réexamen serré des mémoires de l'empereur (ou Jahāngīr Näma). En ressort une voix politique cohérente et originale, Jahāngīr articulant habilement ses identités de souverain, de naturaliste et de collectionneur. La conclusion évalue l'impact de ce discours à travers un rapide analyse de la réaction qu'il suscita auprès de l'élite politique et religieuse du royaume.

Keywords: Mughals, politics, autobiography, naturalism, collections

The child of so many prayers, vows and pilgrimages, the eldest son of the richest and most glorious sovereign of the age, the universal darling in the picturesque palace-city of Fathpur Sikri, he found a path strewn with roses. He was denied the splendid opportunities which form the silver lining of the dense cloud of want and struggle-opportunities of acquiring insight into the human nature; tact and resourcefulness; energy and audacity; in a word, that grit which forms the essence of character. All his life he suffered from weakness of will and resolution, from a lamentable propensity to surrender himself to the mercies of superior talent or craft (...). These defects of character were aggravated by a habit which he contracted on the very threshold of youth and which brought him to an early grave. Intemperance was the besetting sin of the Mughal house. ${ }^{1}$

* CNRS, Paris, co.lefevre@gmail.com

${ }^{1}$ Beni Prasad, History of Jahangir (London: Oxford University Press, 1922): 25-6. 
It is significant that in 1922 Beni Prasad chose these harsh words to open the first modern monograph devoted to the reign of Jahāngīr (1605-1627). However, these lines only present us with some of the vignettes generally associated with this monarch (a weakness of character linked to his being a porphyrogenite, and a self-destructive alcoholism). Among all the emperors of what has sometimes been termed the Mughal "golden age" (1556-1707), Jahāngïr is certainly the one whose political competence has been deemed the weakest. Systematically portrayed as a pale successor of his illustrious predecessor Akbar (r. 1556-1605), he has alternatively been described as a pleasure-seeker who lost himself in alcohol and opium vapours, and a savage righter of wrongs given to sudden fits of cruelty, but also as a refined aesthete with a keen interest in arts, curios, and natural sciences. Beyond these diverse characterizations-which colonial and postcolonial historians have elaborated on in varying degrees - the image of Jahāngir which finally gained the widest currency in the collective memory was that of a sovereign who chose to abdicate all political authority following his marriage with the famous Nūr Jahān in 1611, that is to say only six years after his accession to the Mughal throne. From this date onward until his death in 1627, the empire is thus said to have been governed by a "junta" which, besides Nūr Jahān, also included her father I'timād-ud-daula, her brother Āṣaf Khān, and, according to some interpretations, the prince Khurram and future Shāh Jahān. ${ }^{2}$ However well-entrenched these ideas now are, they should rather be seen as the result of a series of historiographical processes which differed substantially in matters of cultural affiliation and motivation. When the literary traditions that gave birth to the grey legend surrounding Jahāngïr's royal persona are examined, two broad categories of texts immediately come to the fore: first, the accounts of the Europeans (Portuguese, English, Dutch, and Italians) who visited the empire in the first quarter of the seventeenth century, and second the

2 Since its institutionalization by Prasad, History of Jahangir, the "Nūr Jahān junta" thesis has gained wide currency and seems today to be considered by most historians as a nonchallengeable received wisdom. For a recent and significant example of this line of historiography, see Ellison Banks Findly, Nur Jahan: Empress of Mughal India (Delhi: Oxford University Press, 1993). For two notable exceptions, see S. Nurul Hasan, "The Theory of Nur Jahan Junta-A Critical Examination." Proceedings of the Indian History Congress, 21st Session: 1959): 324-335 and Sanjay Subrahmanyam, "Iranians Abroad: Intra-Asian Elite Migration and Early Modern State Formation." Journal of Asian Studies 51/2 (1992): 340-363. As shown by the latter, the "junta" theory is but one interpretation of the political hegemony achieved by the Iranians under Jahāngīr's rule: rather than a sign of weakness, this phenomenon should more fruitfully be seen as the result of the emperor's desire to attract to his court Iranian elites whom he especially valued for their administrative-cum-commercial savoir-faire as well as for their knowledge of the innovative policy implemented by his Safavid rival Shāh 'Abbās (r. 1587-1629). In this light, Nūr Jahān and her family played a crucial—yet subordinate-role as intermediaries. 
Mughal chronicles composed during the reign of Shāh Jahān (1628-1658), the son and successor of Jahāngīr.

True, the former category is itself rather heterogeneous in respect of the authors' identities and objectives as well as the literary forms chosen (letters, journals, treatises, chronicles, etc). The accounts it includes having moreover been written at different times of the Jahāngīin domination, it should not be considered as a monolithic tradition. The reading of the European corpus allows one to delineate three main periods in the reign, each of them bearing the seal of some key texts and each offering a somewhat different portrayal of the emperor. During the first phase-corresponding to the years 1605-1611 and principally documented by the writings of the Jesuit Father Jerónimo Xavier ${ }^{3}$ and William Hawkins ${ }^{4}$-Jahāngīr appears as a fully-fledged monarch who stands out as being strongly involved in the strict application of justice. In the course of the second period (1611-1622), the accounts of the English ambassador Sir Thomas Roe and of his chaplain Edward Terry present us with the image of a politically weakened emperor, dominated by the Nūr Jahān faction. ${ }^{5}$ Finally during the last phase of the reign (1622-1627), the Dutch Francisco Pelsaert ${ }^{6}$ and, to a lesser degree, the Roman traveller Pietro Della Valle ${ }^{7}$ depict

See Ferñao Guerreiro, Jahangir and the Jesuits, trans. C. H. Payne (Delhi: Munshiram Manoharlal, 1997): 3-23, 35-9 for an abridged version of the letters he sent to the Provincial of Goa in 1606-7, and Jorge Flores, "Two Portuguese Visions of Jahangir's India: Jerónimo Xavier and Manuel Godinho de Erédia." In Goa and the Great Mughal, eds. J. Flores and N. V. e Silva (Lisbon: Calouste Gulbenkian Foundation \& Scala Publishers, 2004): 48-56 for a detailed analysis of his Tratado da Corte e Caza de Iamguir Pachá Rey dos Mogores, composed in 1610 .

${ }^{4}$ Following a two-year stay (April 1609-November 1611) at the Mughal court as a representative of the East India Company (EIC), William Hawkins put his mission down in writing; he also composed a "Briefe Discourse on the Strength, Wealth and Government with some Customes of the Great Mogol" which is of much greater interest in the present perspective. See William Foster, ed. Early Travels in India, 1583-1619 (Delhi: Low Price Publications, 1999): 98-114.

5 For an account of this embassy, see Thomas Roe, The Embassy of Sir Thomas Roe to India, 1615-1619, as Narrated in his Journal and Correspondence, ed. W Foster (London: Hakluyt Society, 1899) and Edward Terry, A Voyage to East-India (London, 1777). Despite the two years and a half (January 1616-August 1618) he spent at the Mughal court, Roe failed to obtain the commercial privileges he had come to negotiate on behalf of the EIC.

${ }^{6}$ Pelsaert acted as a factor of the Verenigde Oostindische Compagnie (VOC) in Agra between 1621 and 1627. Besides his well-known Remonstrantie, he composed a Kroniek recounting the history of the Mughal Empire from the 1530s up to the death of Jahāngìr. Half of the latter text is actually devoted to the last years of the sovereign, the account of which focuses on the ubiquitous and mischievous Nūr Jahān. See Francisco Pelsaert, $A$ Contemporary Dutch Chronicle of Mughal India, trans. B. Narain, ed. S. R. Sharma (Calcutta: Susil Gupta, 1957): 36-97.

7 See in particular Pietro Della Valle, The Travels of Pietro Della Valle in India from the Old English Translation of 1664 by G. Havers, edited with a life of the author and intro- 
a very grim situation bordering on civil war: now a real despot ruling the empire according to her own selfish interests, Nūr Jahān fiercely opposes the prince and rebel Khurram in the onset of a struggle for succession. In the course of this last phase, the monarch's personality is definitely deprived of any political depth, and the name of the sovereign is systematically mentioned in a passive mode.

Reviewing this somewhat disparate corpus, the accounts of Thomas Roe and Francisco Pelsaert may certainly be singled out for portraying Jahāngīr in the darkest light. Their characterization of the emperor had, however, little to do with his supposed lack of royal qualities: while, in the case of Roe, it aimed at putting the blame for the failure of the ambassador's mission on Jahāngìr and his government, it was considered by Pelsaert as a most appropriate image to convey a sense of the intrinsic weakness of the Mughal polity to his learned audience. ${ }^{8}$ Significantly enough, both these texts also happened to be the narratives which, thanks to the compilations of Samuel Purchas (Hakluytus Posthumus or Purchas His Pilgrimes, 1625) and Joannes De Laet (De Imperio Magni Mogolis, 1631), gained the widest currency in contemporary Europe. Taken together, they thus heavily influenced the Western perception of the monarch in the subsequent centuries.

When turning to the second tradition briefly hinted at above, Akbar's successor is hardly better off. In this respect, the peculiarity of Jahāngīrī historiography should not be forgotten: when he decided to depart from the chronicle tradition inaugurated by his father and write down the history of his reign in the form of memoirs (or Jahāngìr Näma, on which more below), the emperor actually sealed off his own historiography to a large extent. As a matter of fact, the memoirs are the only contemporary official account available to this day. This key-but isolated and sometimes disconcerting-narrative was soon submerged in the new and massive Shāh Jahānī historiography. Composed with a short interval of the three years that followed Jahāngīr's demise, the Iqbāl Nāma-i Jahāngīrì by Mu'tamad Khān and the Ma'āsir-i Jahāngīrì by Kāmgār Husainī, if no commissioned works, were nonetheless written in order to gain

duction and notes by Edward Grey (Delhi: Asian Educational Services, 1991): 48-59 for a letter dated March 1623 and describing the contemporary political situation.

8 Sanjay Subrahmanyam, "Frank Submissions: The Company and the Mughals between Sir Thomas Roe and Sir William Norris." In The Worlds of the East India Company, eds. H. Bowen and N. Rigby (Woodbridge: The Boydell Press, 2002): 76-8 on Roe; Terry's Voyage functioned in this respect as a handmaid of the ambassador's report. On Pelsaert's Kroniek, which was completed at a time when the struggle for succession had not yet been settled and prognostics still favored Nūr Jahān's candidate Shahriyār, see Sanjay Subrahmanyam, Explorations in Connected History (Delhi: Oxford University Press, 2005): ii: 173-4. 
the favor of the new emperor. ${ }^{9}$ As is well-known, Shāh Jahān had finally ascended the Mughal throne after a five-year rebellion against his father, and both authors were therefore confronted with the arduous task of legitimizing their new master's unorthodox rise to power. They mainly achieved this through a parallel and highly instrumental rewriting of both Salīm/Jahāngīr's and Khurram/Shāh Jahān's revolts_two periods which the Jahāngīr Nāma (starting in 1605 and ending in 1624) had conveniently left totally or partially unmentioned. On the one hand, the portrayal of the insurgent Salim as a debauched prince driven by drugs to inhuman acts of cruelty was manifestly designed to provide the reader with a negative term of comparison in contrast to which Khurram's misconduct could not but appear relatively benign. ${ }^{10}$ On the other hand, the latter's own rebellion was presented as an act of self-defence directed, not at his father, but against the ambitious Nūr Jahān who threatened his legitimate right to ascend the throne. It is thus the empress who essentially stands as the main target of the two chroniclers, and both texts seize the opportunity of the royal espousal in 1611 and of the beginning of Shāh Jahān's revolt in 1622 to respectively alert the reader to this rising figure and then to denounce her nefarious hegemony over Mughal politics. ${ }^{11}$ While staging Nūr Jahān as the villain of the piece, Mu'tamad Khān and Kāmgār Ḥusainī pushed Jahāngīr into the background and readily sacrificed his political reputation for the sake of his son's legitimacy. Being the first Mughal histories to provide a continuous narrative of the years 1622-1627 and a clever justification of Shāh Jahān's rebellion, these works were-not surprisingly-heavily relied upon by the authors of the numerous chronicles subsequently commissioned by the new emperor. ${ }^{12}$ The tradition thus formulated was continued, albeit with slight adaptations, by most eighteenth-century synoptic chronicles such as Khāfî Khān's Muntakhab-ul-lubāb. ${ }^{13}$

${ }^{9}$ For these two histories of Jahāngīr's reign, see Muhammad Sharīf Mu'tamad Khān, Iqbāl Nāma-i Jahāngìrī, eds. M. Abdullah and A. Ali (Osnabrück: Biblio Verlag, 1982) and Ghairat Khāan (Khwāja) Kāmgār Husainī, Ma'āṣir-i Jahāngīrī, ed. A. Alavi (Bombay: Asia Publishing House, 1978).

${ }^{10}$ See especially Kāmgār Husainī, Ma’āsirr-i Jahāngīrī: 42-6. Rather ironically, Shāh Jahān's rebellion was actually much more violent than that of his father who never took up arms against Akbar. It should moreover be noted that the acts of cruelty mentioned in the $M a^{\prime} \bar{a}$ sir- $i$ Jahāngīri surface nowhere in the contemporary Jesuit accounts.

11 Mu'tamad Khān, Iqbāl Nāma-i Jahāngīrī: 54-7, 196-9 and Kāmgār Husainī, Ma’āsirir-i Jahāngīrī: 143-4, 350-361.

12 This is particularly the case of the Bādshāh Nāma by Mìrzā Amīn Qazwīnī (1638) and of the 'Amal-i Șālih by Muḥammad Șālih Kambū Lāhaurī (1671), two works which dealt at length with Khurram's princedom, even though the latter was a non-official history.

${ }_{13}$ Significantly, the only written sources (other than the memoirs) Khāfî Khān refers to in his chapter on Jahāngīr are the Iqbāl Nāma, the Ma'āsir-i Jahāngīrī, and the Bādshāh Nāma 
Although informed by altogether different ideological motives from those underlying the European travelogues of the seventeenth century, the Mughal historiography on Jahāngir nonetheless combined with these accounts to fuel the unflattering judgement most historians of the colonial and postcolonial periods subsequently came to pass on the monarch. While Nūr Jahān has been the object of unfailing scholarly attention for the past two centuries, no serious monograph has been devoted to Jahāngīr as a sovereign since the 1920s and the publication of Beni Prasad's book. In this respect, the silence of the dominant "Aligarh school" is particularly significant and acts as a useful reminder of how prejudicial the focus on Akbar's and Aurangzeb's reigns has been (and still is) in the study of Mughal India in the first half of the seventeenth century. ${ }^{14}$ For all that, one should not paint things blacker than they are. In the last fifty years, some scholars have drawn attention to some aspects of Jahāngīr's political personality as well as to the contemporary evolution of Mughal ideology, ${ }^{15}$ and a number of art historians have highlighted the visual strategies he implemented in order to sustain imperial claims. ${ }^{16}$ In spite of these welcome contributions, a global re-evaluation of the reign is still acutely missing. One way of filling this gap is, as I have argued elsewhere ${ }^{17}$ to subject the Jahāngīin imperium to a thorough analysis that (i) gives the monarch's voice back to him through a careful re-examination of the imperial discourse which encompassed the spheres of

by Qazwīnī. See Khāfī Khān, Muntakhab-ul-lubāb, ed. K. Ahmad, 3 vols. (Osnabrück: Biblio Verlag, 1983): i: 247-8.

14 For exceptions, see for example Irfan Habib, "The Family of Nur Jahan during Jahangir's Reign: A Political Study." In Medieval India-A Miscellany (Bombay: Asia Publishing House, 1969): 74-95 and, more recently, Afzal Husain, The Nobility under Akbar and Jahāngīr: A Study of Family Groups (Delhi: Manohar, 1999). However, none of these works calls into question the received wisdom on Jahāngir.

15 John F. Richards, "The Formulation of Imperial Authority under Akbar and Jahangir." In Kingship and Authority in South Asia, ed. J. F. Richards (Madison: South Asian Studies, University of Wisconsin, 1978): 252-285, Sajida Sultana Alvi, "Religion and State during the Reign of the Mughal Emperor Jahangir (1605-1627)." Studia Islamica 79 (1989): 95-119, and Munis Daniyal Faruqui, "Princes and Power in the Mughal Empire, 1569-1657," PhD. (Duke University, 2002): 50-269.

${ }^{16}$ Richard Ettinghausen, “The Emperor's Choice." In De Artibus Opuscula XL: Essays in Honor of Erwin Panofsky, ed. M. Meiss (New York: New York University Press, 1961): 98-120, Robert Skelton, "Imperial Symbolism in Mughal Painting." In Content and Context of Visual Arts in the Islamic World, ed. P. Soucek (London and University Park: Pennsylvania State University Press, 1988): 177-187, Gauvin Alexander Bailey, "The Indian Conquest of Catholic Art: The Mughals, the Jesuits and Imperial Mural Painting." Art Journal 57/1 (1998): 24-30, Ebba Koch, Mughal Art and Imperial Ideology: Collected Essays (Delhi: Oxford University Press, 2001), and Heike Franke, Akbar und Gahāngīr: Untersuchungen zur politischen und religiösen Legitimation in Text und Bild (Schenefeld: EB-Verlag, 2005).

17 Corinne Lefèvre, Pouvoir et élites dans l'Empire moghol de Jahāngīr (r. 1605-1627) (Paris: Les Indes Savantes, forthcoming). 
chronicling, painting, architecture, and numismatics, and (ii) assesses the reactions this discourse elicited from its intended audience-the military-administrative and religious elites of the realm - through the critical reading of a series of texts produced by, or at the behest of, these groups. ${ }^{18}$ While addressing the latter question by way of conclusion, the present article will, however, focus (almost) exclusively on Jahāngïr's memoirs - as this text stands in my eyes as the necessary starting point for every re-evaluation of the reign and has not, contrary to the paintings or buildings the emperor commissioned, benefited from any new insightful treatment nor received the amount of attention it deserves. ${ }^{19}$ But before dealing with the Jahāngīr Nāma, it may be useful to say a few words on the tradition it stemmed from.

\section{THE JAHĀNGĪR NĀMA AND THE TIMURID TRADITION OF IMPERIAL MEMOIRS}

The Timurid tradition of imperial memoirs goes back to Tīmūr himself (d. 1405) who was, with Chingīz Khān (d. 1227), the most eminent ancestor of the Mughal dynasty. Written in Chaghatāy Turkish (the spoken language of Tīmūr), the Malfużāt-i Tìmūrì give an account of his life, from his seventh year to his death, and are followed by an appendix called the Tüzukāt-i Tìmūrì, which records the regulations of the monarch. Albeit composed in the first person and long-attributed to Tìmūr, the Malfużāt were not his personal work, but most probably that of one of his close relations who started writing the text not

18 Among the most significant texts documenting the viewpoint of the umara $\bar{a}^{3}$ are: the Tārīkh-i Khān Jahānī wa Makhzan-i Afghānī (1613) by Khwāja Ni'matullāh Harawī and the Ma'āsir-i Rahīmī (1616) by 'Abd-ul-Bāqī Nahāwandī-two sub-imperial chronicles respectively dedicated to the Afghan Khān Jahān Lodī and the Iranian 'Abd-ur-Rahīm Khān-i Khānān; the Mau'iża-i Jahāngīrī (1612), a work of advice composed by the Iranian amīr Muhammad Bāqir Najm-i Sānī and dedicated to the ruling monarch; the Virsimhdevcarit and the Jahāngīrjascandrikā-two historical poems composed in brajbhāṣā by Keshav Dās, a poet patronized by the Rājpūt chief and amīr Bīr Singh Deo. As for the reaction of the religious elite, it is first important to note that, apart from a bunch of exceptions, most of the contemporary sources penned by members of this group and dealing with Jahāngīr's policy are the work of Muslim writers. Among those, the Risāla-i Nüriyya-i Sultāniyya (early 1610s?) and the Akhlāq-i Jahāngīrì (1620-1622)—two treatises of government respectively composed by the 'ulamā' Shaikh 'Abd-ul-Haqq Muhạaddis Dihlawī and Nūr-ud-dīn Qāzị̂-ul-Khāqānī and dedicated to Jahāngìr - are of prime importance, while contemporary and slightly later Sufi literature (tazkiras or bio-hagiographical dictionaries, maktūbāt or collections of letters) also yields invaluable information. For a survey of the latter corpus, see Saiyid Athar Abbas Rizvi, A History of Sufism in India (Delhi: Munshiram Manoharlal, 2002).

19 Despite her claims, Lisa Balabanlilar, "Lords of the Auspicious Conjunction: Turco-Mongol Imperial Identity on the Subcontinent." Journal of World History 18/1 (2007): 1-39 does not closely or critically engage with the Jahāngīr Näma as a text. 
long after $1405 .{ }^{20}$ For the present purpose, the literary precedent thus established - the recording of events in the guise of royal memoirs-is, however, much more important than the question of authenticity.

A century later, this precedent was significantly resumed by the founding father of the Mughal dynasty, Bābur (r. 1526-1530). Similarly composed in Chaghatāy Turkish - a language which had been reflourishing in the Timurid Herat of Sultān Husain Baiqarā (r. 1470-1506) — his memoirs cover a period stretching from 1494 to 1529. Built along an annalistic framework, the Bābur Nāma consists of three parts which respectively deal with the life and career of the prince in Ferghana and Transoxiana (1494-1503), Kabul (1504-1525), and India (1526-1529). While the first two parts were carefully edited by their author, the last one is unfortunately more of a rough sketch, leaving the reader with a feeling of a work still in progress - a feeling somewhat strengthened by the fact that Bābur apparently never bothered to give his account a title. Due to the loss of folios from the original manuscript, some sections of the Kābuli section are moreover missing. The value of the memoirs is, however, not to be underrated for they allow us not only to reconstruct the history of contemporary Central Asia and northern India to a large extent, but also to capture the personal voice of a ruler of the early modern Islamic world. Besides his recording of political events, Bābur's numerous introspective remarks and digressions on the flora, fauna, or populations he encountered on his way endow his account with a rare quality of liveliness and humanism. Finally, on the more abstract level of imperial culture and ideology, the memoirs provide us with a precious insight into the political horizon of a sixteenth-century Timurid prince: from this point of view, the Bābur Nāma may be considered as a work of legitimization simultaneously addressed to the ruler's close supporters, the competing Timurid and Chingīz Khānī factions of Central Asia, and the Muslim elites of Hindustan. ${ }^{21}$

The upheavals that followed Bābur's death and extended well into the chaotic reign of his son Humāyūn (1530-1540 and 1555-1556) largely account for the fact that the circulation of the memoirs was at first very limited in scope.

${ }^{20}$ Irfan Habib, "Timur in the Political Tradition and Historiography of Mughal India." In Cahiers d'Asie centrale, vols. 3-4: L'héritage timouride, Iran-Asie centrale-Inde, XV -XVIII siècles, dir. M. Szuppe (Tashkent and Aix-en-Provence: Édisud, 1997): 308.

${ }^{21}$ For traditional views on this question, see Stephen F. Dale, The Garden of Eight Paradises: Bābur and the Culture of Empire in Central Asia, Afghanistan and India (14831530) (Leiden: E. J. Brill, 2004): esp. ch. 3; for a stimulating reinterpretation distinguishing between the legitimizing rhetoric at work in Central Asia and Afghanistan on the one hand, and in India on the other, see Ali Anooshahr, "Disclaiming Tamerlane's Inheritance and the Rise of the Mughal Empire." Paper presented at the Clark Library Conference, "Imperial Models and the 'Translatio Imperii': Rethinking the Early Modern World," 3-4 November 2006. 
Indeed, no copy of the original text seems to have been commissioned after the monarch's demise, and the Mughal amīr 'Abd-ur-Rahīm Khān-i Khānān had to work on the autograph manuscript when asked by Akbar to translate the work into Persian - a task which he completed in 1589. Unlike the Chaghatāy original, the Persian version enjoyed a very wide circulation. This "editorial success" was of course intimately linked to the changing circumstances of the second half of the sixteenth century, which witnessed the strengthening of Mughal power and the concomitant rise of Persian as the new language of culture and administration. That Jahāngīr chose, unlike his great-grandfather, to write his own memoirs in Persian is a powerful sign of this evolution. Bābur's literary personality and work were nonetheless highly influential on Akbar's son when he, in turn, decided to put the events of his life down in writing. While visiting Kabul in the summer of 1607 , he himself alluded to this particular affiliation:

I was shown His Majesty Firdaus-Makānī [Bābur]'s memoirs. They were entirely in his own blessed handwriting, except for four sections I copied myself. At the end of these sections I penned a sentence in Turkish to show that the four sections were in my writing. Although I grew up in Hindustan, I am not ignorant of how to speak or write Turkish. ${ }^{22}$

Unlike Bābur however, Jahāngīr did give his account a title: the Jahāngīr Nāma or Book of Jahāngìr. Beginning with the accession to the throne, its writing continued until 1622 when, weakened by illness, the emperor entrusted his secretary Mu'tamad Khān (also the author of the Iqbāl Nāma) with the task of recording all subsequent events of the reign. ${ }^{23}$ The two men worked together until 1624, at which point the text abruptly stops.

As mentioned earlier, the monarch also followed a different linguistic path from that of his ancestor. This choice did not mean that he adopted the prolix and convoluted style typical of most contemporary Mughal chronicles: far from being pompous or archaic, his language is both informal and fluent. In accordance with the literary practice of the time, he did, however, pepper his text with poetic quotations from classical Persian authors such as Firdausī, Niżāmī, and $\mathrm{Sa}^{\mathrm{c}} \mathrm{di}$ or Hāfiż. ${ }^{24}$ But from a linguistic point of view, the diversity of the languages used by Jahāngīr in his work is probably its most salient featurethe Persian narrative being interspersed with Turkish, Hindūstānī, or Kashmīrī words. While most of the former are linked to the military and ceremonial

22 Jahāngīr, Jahāngīr Nāma: Memoirs of Jahāngīr, Emperor of India, trans. W. M. Thackston (Washington D. C. and New York: Freer Gallery of Art and Arthur M. Sackler Gallery, Smithsonian Institution \& Oxford University Press, 1999): 77.

23 Jahāngīr, Jahānḡ̄r Nāma: Memoirs of Jahāngīr: 386.

24 Jahāngīr, Jahāngīr Nāma: Memoirs of Jahāngīr: 389; 405; 33, 202, 213, 388; 46, 132, 222. 
spheres, the latter's use ranges much wider and is not merely confined to the naming of Indian specificities. Jahāngïr's sensitivity to his Indian environment is also apparent in his familiarity with Hindūstānī poetry and its imagery: the sight of a field of water lilies thus reminds him of a common amorous metaphor in Hindūstānī poetry - that of the lotus flower and the black bee-and of Tansen's verses. ${ }^{25}$ The deliberate use of these words certainly endows Jahāngīr's Persian with a kind of "Indianness"; ${ }^{26}$ it also testifies to the process of Indianization (or indigenization) that Mughal power had been undergoing since the last third of the sixteenth century, notably through the Rājpūts' integration into the ranks of nobility.

In respect of internal organization, the Jahāngìr Näma-similar to the Bābur Näma-follows a chronological sequence and gives a year-by-year account of events. Like its model, it also makes room for numerous digressions of varying nature. Some passages are devoted to the history or geographical description of the regions toured by the emperor: his stay in Mandu (March-October 1617) thus gave him the chance to relate some episodes of the life of the sultans of Malwa, ${ }^{27}$ while his regular travels to Kashmir allowed him to pay a stirring homage to the natural beauties of this paradise on earth. Other passages contain bits of ethnological, zoological, or botanical investigation ${ }^{28}$ and bring out a prominent facet of Jahāngīr's character, i.e. his "scientific" curiosity and the importance he attached to experimentation in accumulating knowledge (on which more below). To a lesser extent than the Bäbur Näma, the memoirs also provide us with a glimpse of the monarch's intimacy-whereas he willingly acknowledges his addiction to drugs, he significantly remains very silent on his relationship with Nūr Jahān—and spiritual life (through, for example, the account of his conversations with the Hindu ascetic Jadrūp). To conclude this general presentation of the text, it should be added that it includes a multitude of administrative information: thanks to the recording of promotions and demotions,

25 Jahāngīr, Jahāngīr Nāma: Memoirs of Jahāngīr: 239. Also very interesting is the fact that he thereafter mentions the corresponding metaphor in Persian poetry-that of the rose and the nightingale.

${ }^{26}$ Jahāngīr, Jahāngīr Nāma: Memoirs of Jahāngīr: xvi.

27 Jahāngīr, Jahāngīr Nāma: Memoirs of Jahāngīr: 214-5, and 149-152 for an excursus on the Rānās of Mewar and their fight against the Mughals.

${ }^{28}$ For ethnology, see Jahāngīr, Jahāngīr Nāma: Memoirs of Jahāngīr: 142-3, 181, and 304 on the Maghs from Arakan. Jahāngīr's interest in tribal peoples also manifested itself in painting as shown by a miniature dated 1615-1620, see Oleg Akimushkin, et al. eds. The St. Petersburg Muraqqa': Album of Indian and Persian Miniatures from the 16th through the 18th Century and Specimens of Calligraphy by Imād al-Hasanī (Milan: ARCH Foundation \& Lugano and Leonardo Arte srl., 1996): pl. 193. See also Jahāngīr, Jahāngīr Nāma: Memoirs of Jahāngìr: 255, 266, 269-270 on zoology; 24, 333 on botany. 
and of the titles bestowed on imperial servants, the career of a great number of manșabdārs (dignitaries) may be, at least partially, pieced together.

Having outlined the main features of the Jahāngìr Näma, it is now time to focus on three interrelated self-representations forcefully drawn upon by the emperor in his memoirs: the sovereign, the naturalist, and the aesthete-cum-collector.

\section{THE BUSINESS OF KINGSHIP}

As mentioned above, conventional historiography generally has it that Jahāngìr was, of all Mughal emperors, the one who took the slightest interest in the business of kingship. The following statement of the monarch, however, runs against this widespread assumption:

When a fair copy of the events of twelve years in the Jahängìr Näma had been made, I ordered the supervisors of the royal library to make one volume of the twelve years and produce multiple copies for me to award to particular servants (bandahä-ye khässs) and to be sent to other regions [of the empire] to be used by the administrators and auspicious as a manual for ruling (dastür-ul-'amal) ${ }^{29}$

There thus seems to be some sort of misunderstanding between Jahāngīr's self-perception of his political role and the way modern historians have so far interpreted it. Focusing on the political culture and practice of the monarch as they are described in the memoirs should, however, help to clear things up.

\section{The Role of Islam}

Assessing the role of Islam in Jahāngīr's political thought and the nature of his relations with the Muslim elite and institutions are two different-yet connected-questions. On the one hand, there are a number of elements that indicate that the monarch attempted to conciliate the 'ulama' and the religiousminded members of the Muslim nobility, a group that Akbar had largely alienated by the end of the sixteenth century. ${ }^{30}$ Hoping to attract their support in the oncoming struggle for succession against his elder son Khusrau, Salīm/Jahāngīr bestowed numerous favors on them during the time of his rebel-

${ }_{29}$ Jahāngīr, Jahāngì̀r Nāma: Memoirs of Jahāngīr: 271. W. M. Thackston's translation has been slightly modified here to conform more closely with the Persian text: Jahāngīr, Jahāngīr Nāma: Tūzuk-i Jahāngīrī, ed. M. Hashim (Tehran: Intishārāt-i Bunyād-i Farhang-i Irān, 1980): 270 and Jahāngīr, Tūzuk-i Jahāngīrī, ed. S. A. Khan (Ghazipur and Aligarh, 1864): 239.

${ }^{30}$ Iqtidar Alam Khan, “Akbar's Personality Traits and World Outlook-A Critical Reappraisal." In Akbar and his India, ed. I. Habib (Delhi: Oxford University Press, 2000): 79-96. 
lion in Allahabad (1599-1605). ${ }^{31}$ That his efforts were adequately rewarded is, for instance, illustrated by the support Mìrān Șadr Jahān-the șadr-uș-ṣudur or chief justice of the empire-and Shaikh Farīd Bukhārī-a high-ranking amìr renowned for his patronage of 'ulama $\vec{a}$ and Sufis-lent to his bid for power. Once on the throne, however, the new emperor's position remained precarious as Khusrau kept threatening his power (he rebelled in April 1606): in order to firmly establish his authority, he had to gather around him the widest possible range of partisans. The great campaign of communication he directed at the conservative Muslims soon after his accession was only one element of this ambitious program. It accounts for his early confirmation of every existing religious grant of land (madad-i mac $\bar{a} s h$ ) and for the public homage he paid to their beneficiaries: according to the memoirs, the latter were an "army of prayer" (lashkar-i $\left.d u^{(} \bar{a}^{\prime}\right)$ in the service of the empire. ${ }^{32}$ Moreover, Mīrān Șadr Jahān was appointed as chief justice, and seems to have been given a free hand in allocating new grants. ${ }^{33}$ Jahāngīr's eagerness to win the 'ulama $\bar{a}$ ' to his cause also led him to participate in public Muslim festivals, and to present himself as a pious monarch. ${ }^{34}$ Following the suppression of Khusrau's rebellion, the consolidation of imperial power certainly allowed the monarch to moderate the orthodox rhetoric of his first years, but he never altogether withdrew from this course of action. In 1611, he indeed decided to comply with an old and symbolic request of the 'ulama' by exempting the chief justice and the qāzis from prostrating before him. ${ }^{35}$ Furthermore, the imprisonment of the famous Shaikh Ahmad Sirhindī was very probably motivated by the 'ulamä's's complaints about the heterodox teachings of the Naqshbandi Sufi. ${ }^{36}$

For all that-and this is a crucial point - the signs of appeasement that Jahāngir showed to the conservative Muslim elite never meant a reversal toward a strict Islamic ideology. His adoption, on his accession, of the honorific title "nūr-ud-dīn" or "light of religion" clearly signalled his adherence to the illuminist theory of sovereignty that was eventually favored by his father. Still following the path opened by the latter, he continued to present himself as a pir

31 Faruqui, "Princes and Power in the Mughal Empire": 92-5.

32 Jahāngīr, Jahāngīr Nāma: Memoirs of Jahāngīr: 27.

${ }^{33}$ Henry Miers Elliot and John Dowson, eds. The History of India as Told by its Own Historians, 8 vols. (Delhi: Low Price Publications, 2001): vii: 447-8. A number of preserved farmāns show, however, that Jahāngīr had no qualms about cutting or cancelling the grants of those who had broken their obligations. See, for instance, Sayyid Akbarali Ibrahimali Tirmizi, Mughal Documents (1526-1627) (Delhi: Manohar, 1989): n²06 and 212.

34 Jahāngīr, Jahāngīr Nāma: Memoirs of Jahāngīr: 44, 31.

35 Jahāngīr, Jahāngīr Nāma: Memoirs of Jahāngìr: 126.

${ }^{36}$ Muzaffar Alam, The Crisis of Empire in Mughal North India: Awadh and the Punjab, 1707-1748 (Delhi: Oxford University Press, 2001): 116. 
(spiritual master) and to appoint disciples from among the amirss. ${ }^{37}$ Nor did he adopt the ruler's duties as described in the legal literature and $\bar{a} \bar{d} \bar{b} b$ texts, such as the protection of Islam or the enforcement of the $\operatorname{shari~}^{c} a$ in the juridical sense of this term. References to Islam as a driving force behind political thought and action are actually very scarce — and most often indirect —in the remainder of the memoirs. ${ }^{38}$ In this context, the orthopraxy Jahāngīr exhibited on his visit to the recently conquered Kangra fort may appear surprising at first sight; however, rather than deriving from a sudden outburst of religious zeal, the Islamization of the citadel was most probably meant to symbolize its submission to a Muslim political power. ${ }^{39}$ The pragmatism of the monarch equally manifested itself in the conversations he had with Sufis and 'ulamä': Jahāngīr may have been as fond of those meetings as his predecessors, but he significantly never asked his religious interlocutors for political advice. ${ }^{40}$ Indeed, while he rightly perceived the necessity of winning back the support of the 'ulam $\bar{a}$ ' and made a number of concessions in order to do so, Jahāngīr simultaneously reasserted an ideology which derived, not from Islamic juristic norms, but from a literary tradition that was much more secular in nature.

\section{The Akhlāqī Tradition}

Although no work of $a \underline{k h l a} q$ (ethics, moralia) is referred to in the memoirs, the influence of this genre is clearly visible in some distinctive features of the emperor's writing. ${ }^{41}$ First, Jahāngīr shared with medieval authors of advice lit-

37 While this continuity is made clear right from the opening pages of the memoirs (Jahāngīr, Jahāngīr Nāma: Memoirs of Jahāngīr: 53), it is also borne out by numerous contemporary sources, such as Mìrzā Nāthan, Bahāristān-i Ghaib̄i: A History of the Mughal Wars in Assam, Cooch Behar, Bengal, Bihar and Orissa during the reigns of Jahāngīr and Shāh Jahān by Mìrzā Nāthan, trans. M. I. Borah, 2 vols. (Gauhati: Government of Assam, 1936): i: 17 and 74 or the miniature painted portraits and portrait coins produced for imperial worship.

38 See for instance Jahāngīr, Jahāngīr Nāma: Memoirs of Jahāngīr: 26 (for the prohibition of alcohol manufacturing and selling) and 76 (for the abolition of "heretical" taxes).

39 Jahāngīr, Jahāngīr Nāma: Memoirs of Jahāngīr: 374. Similarly, when describing Akbar's campaign against Hemu as a ghazā or calling Rāja Bikramājīt—who had just joined the ranks of Shāh Jahān's rebellion-a "Hindu dog," Jahāngīr clearly manipulated the religious idiom in order to weaken the reputation of people who were, above all, political opponents (Jahāngīr, Jahāngīr Nāma: Memoirs of Jahāngīr: 41, 316).

${ }^{40}$ See, for instance, Jahāngīr, Jahāngīr Nāma: Memoirs of Jahāngīrr: 251, 316, 320, and 366.

${ }^{41}$ For a powerful analysis of $a \underline{k h l a ̄ q ~ l i t e r a t u r e ~ i n ~ t h e ~ I n d o-M u s l i m ~ c o n t e x t, ~ s e e ~ M u z a f f a r ~}$ Alam, "A $\underline{k h l a ̄ q i}$ Norms of Mughal Governance." In The Making of Indo-Persian Culture: Indian and French Studies, eds. M. Alam, F. N. Delvoye and M. Gaborieau (Delhi: Manohar, 2000): 67-95. 
erature a taste for edifying anecdotes. The best example of this tendency is his story of a king and a gardener which shows how much the prosperity of a kingdom depends on the good intentions of its ruler. ${ }^{42}$ In this respect, the text comes very close to the idea of the "circle of justice" and to the topos of a meeting between the humble subject and the king-two features that figure prominently in works of advice. ${ }^{43}$ Second, Jahāngīr often ends his account of some political event with a maxim. ${ }^{44}$ Last, the animal stories he is so fond of telling sometimes bear a strong resemblance to moral, even political, fables.

Apart from the Jahāngìr Nàma, there are a number of indications that point to the monarch's familiarity with the $a \underline{k h} l \bar{a} q$ literature. As underlined by Muzaffar Alam, the Mughal princely curriculum included (at the very least) an introduction to $a \underline{k h l a} q$ literature through the study of classics such as the Akhlāq-i Nāṣirī by Nāṣir-ud-dīn Ṭūṣī (1235) or the Akhlāq-i Jalālì by Dawwānī (d. 1502). ${ }^{45}$ Moreover, an illustrated copy of the former philosophic-ethical treatise was produced in Akbar's workshop in 1595, and Jahāngīr most likely took a great interest in it. ${ }^{46} \mathrm{He}$ himself ordered the translation into Persian of Ibn Miskawaih's al-Hikma al-Khālida, a collection of Greek, Iranian, Indian, and Arab maxims,${ }^{47}$ and no less than three works of advice were dedicated to himthe Risāla-i Nüriyya-i Sultāniyya, the Mau'iża-i Jahāngīrī, and the Akhlāq-i Jahängìr-even though only the second work truly belonged to the akhlàq genre. ${ }^{48}$ Most important, however, is the fact that the ideology articulated in the

42 Jahāngīr, Jahāngīr Nāma: Memoirs of Jahāngīr: 284-5.

${ }^{43}$ See Linda T. Darling, "'Do Justice, Do Justice, For that is Paradise': Middle Eastern Advice for Indian Muslim Rulers." Comparative Studies of South Asia, Africa and the Middle East 22/1-2 (2002): 3-19 for a useful synthesis on the idea of the "circle of justice."

44 These ethical-political maxims often appear in the form of poetic quotations. A meaningful example is the account of 'Abd-ur-Rahīm Khān-i Khānān's desertion to the rebellious Shāh Jahān; it ends with the following verses of Sa'dī: "In the end a wolf cub becomes a wolf, even if it has grown up among humans" (Jahāngīr, Jahāngīr Nāma: Memoirs of Jahāngìr: 388).

45 Alam, "A $\underline{k h l a ̄ q i}$ Norms of Mughal Governance": 84.

46 Anthony Welch and Stuart Cary Welch, Arts of the Islamic Book: The Collection of Prince Sadruddin Aga Khan (Ithaca and London: Cornell University Press, 1982): 173-5.

47 Alam, "A $\underline{k h l a ̄ q i}$ Norms of Mughal Governance": 87. For a contemporary account of the translation, see 'Abd-us-Sattār b. Qāsim Lāhaurī, Majālis-i Jahāngìrī, eds. A. Naushāhī and M. Niżāmī (Tehran: Mīrās-i Maktub, 2006): 90 and 127.

${ }_{48}$ Although the Risāla-i Nüriyya-i Sultāniyya and the Akhlāq-i Jahāngìrī put on the garb of $a \underline{k h l a} q \bar{l}$ works, the ideology underlying them actually derived from the juristic tradition of Islam. On the former, see Lefèvre, Pouvoir et élites dans l'Empire moghol de Jahāngīr: part 3, and Alam, "A $\underline{k h l a ̄ q i ̄ ~ N o r m s ~ o f ~ M u g h a l ~ G o v e r n a n c e ": ~ 88-90 ~ o n ~ t h e ~ l a t t e r . ~ T h e ~ M a u ' i z ̇ a-~}$ $i$ Jahāngīrī has been edited, translated and commented by S. S. Alvi: Muhammad (Najm-i Sānī) Baqīr Khān, Mau'iża-i Jahāngīrī. Advice on the Art of Governance: An Indo-Islamic Mirror for Princes of Muhammad Bāqir Najm-i Sānī (Albany: State University of New York Press, 1989). 
Jahāngìr Nāma owed a great deal to the notions developed by the akhlāq tradition. As noted above and more fully explored below, Jahāngīr considered his role as a monarch not so much to be defined by the enforcement of a legallydefined $\operatorname{sharī}^{c} a$, but by a total dedication to justice (' $a d l$ ).

However, in everyday administration and in matters of political decisions, his eminent ancestors-from Chingīz Khān to Akbar-provided the monarch with a more easily accessible dynastic legacy on which he pointedly modelled himself.

\section{The Dynastic Legacies}

Within the set of dynastic precedents available to Jahāngīr, the references to Chingiz Khān in the memoirs may be singled out for their homogeneity. On the one hand, they are very few in number (three occurrences) and are closely gathered in the space-time continuum of the narrative. ${ }^{49}$ Each of them appears during the first regnal year (1605-1606), i.e. at a time when Jahāngīr's authority was far from being firmly established. On the other hand, every one of them refers to the türa-i chingīzi —a body of rules supposedly instituted during Chingīz Khān's reign. ${ }^{50}$ Finally, all but one of them are connected with questions of etiquette. Within this framework, two sections are particularly significant: the first describes the introduction by Jahāngìr of a form of inalienable jāgìrs (land grant) in accordance with the "Chingīz Khānī custom and rule (tūra wa qānūn-i chingīzì)," and the conformity to this "code" also underlies the ceremonial surrounding the coming to the imperial camp of the vanquished Khusrau. By referring in both cases to the tūra-i chingīzì, Jahāngīr obviously sought to legitimize his concessions in matters of land revenue and his treatment of a disgraced prince. For all that, when trying to assess the overall role of Chingīz Khān's legacy in the memoirs, it appears to have been very limited: it was nothing else than a legitimizing relic occasionally used in times of political uncertainty.

While the references to Tìmūr are far more numerous than those to Chingīz Khān, they differ radically from the latter in their nature. They may schemati-

49 Jahāngīr, Jahānḡ̄r Nāma: Memoirs of Jahāngīr: 32, 57-8, 61.

50 There is a very extensive literature on the related questions of the tūra and yāsā of Chingīz Khān. For a recent and global reassessment, see Denise Aigle, "Le grand Jasaq de Gengis-Khan, l'Empire, la culture mongole et la sharī'a." Journal of the Economic and Social History of the Orient 47/1 (2004): 31-79; for an analysis focused on Indian sources, see Mansura Haidar, "The Yasai Chingizi (Tura) in the Medieval Indian Sources." In Mongolia: Culture, Economy and Politics (Indian-Mongolian Assessment), eds. S. Bira et al. (Delhi: Khama Publishers, 1992): 53-66. 
cally be divided in two broad categories. The first body of occurrences refers to Tīmūr's career as a world conqueror. During his 1398-1399 campaign in Hindustan, Tīmūr is said to have given a group of his retainers (the Qārlughs) some land in northern Singh Sagar Doab and, according to Jahāngïr, this area was still occupied by their descendants in the seventeenth century. ${ }^{51}$ By underlining the antiquity of Timurid establishment in India, the monarch obviously aimed at presenting the Mughal presence in the region as the outcome, not of sheer conquest, but of a rightful recovery of the territories lost after Tīmūr's death. The insertion of this particular episode in the memoirs is all the more significant since it had completely disappeared from the Mughal chronicles written after the Bābur Nāma-Tìmūr's depredations in India being deemed by most authors as a great liability. ${ }^{52}$ Its reappearance in the Jahāngīr Nāma should probably be seen as a response to the new Timurid connections drawn up by contemporary Safavid ideology and historiography. ${ }^{53}$ Additionally, references to the conquering Tīmūr were used to legitimize Mughal claims on Transoxiana-the homeland (watan) of the Timurids which had been won over by the Shaibani Uzbeks in the first quarter of the sixteenth century. ${ }^{54}$ Jahāngīr also called on Tīmūr's war achievements to emphasize Mughal prestige vis-à-vis other Muslim dynasties, especially the Ottomans whose ruler Sultān Bāyazīd (r. 1389-1402) had been so famously defeated by the world conqueror. ${ }^{55}$ The second body of occurrences pertains to Jahāngìr's efforts to connect himself with the Timurids through objects having once belonged to them. Significantly, all but one of these dynastic memorabilia, as Thomas Lentz aptly coins them, ${ }^{56}$ were presents of the Safavid monarch Shāh 'Abbās who, thereby, sought to wheedle the Mughal ruler into surrendering the Qandahar fortress. ${ }^{57}$ Jahāngīr's assertion of his Timurid identity moreover manifested itself through the inscriptions he liked to scatter along his way: during his stay in Kabul in the summer of 1607, he twice had his name and those of his ancestors up to Tīmūr engraved in stone. ${ }^{58}$

51 Jahāngīr, Jahāngīr Nāma: Memoirs of Jahāngīr: 324.

52 Habib, "Timur in the Political Tradition and Historiography of Mughal India": 1997.

${ }^{53}$ See Sholeh A. Quinn, Historical Writing During the Reign of Shah 'Abbas: Ideology, Imitation, and Legitimacy in Safavid Chronicles (Salt Lake City: University of Utah Press, 2000) for the role played by Timurid connections in Safavid historiography.

54 Jahāngīr, Jahāngīr Nāma: Memoirs of Jahāngīr: 33, 68.

55 Jahāngīr, Jahāngīr Nāma: Memoirs of Jahāngīr: 95.

56 Thomas W. Lentz and Glenn D. Lowry, Timur and the Princely Vision: Persian Art and Culture in the 15th century (Los Angeles: Los Angeles County Museum of Art, 1989): 320.

57 Jahāngīr, Jahāngīr Nāma: Memoirs of Jahāngīr: 319 for a painting of Tīmūr's battle with Iletmish Khān, and 357 for a spinel of Ulugh Beg (r. 1447-1449), one of Tìmūr's grandsons.

58 Jahāngīr, Jahāngīr Nāma: Memoirs of Jahāngīr: 76-7. 
Finally, in much the same way as his predecessors and successors, he generously contributed to the maintenance of the Gur-i Amir (Tìmūr's mausoleum in Samarqand) and its staff. ${ }^{59}$ Apart from the memoirs, other sources interestingly attest to the importance Jahāngir attached to the Timurid reference: these are, on the one hand, the books and paintings in the imperial library (on which more below) and, on the other hand, literary accounts produced outside of India such as Mutribī-ul-Asamm Samarqandī's recording of his conversations with the monarch. ${ }^{60}$ In the light of the above evidence, it is therefore clear-at least in the case of Jahāngìr - that the Timurid legacy was of a territorial and cultural (even sentimental), rather than strictly political, nature. While the figure of Tīmūr is indeed used to legitimize Mughal claims on specific regions, it is, however, never associated with a political decision or action. In this respect, Akbar stands as the ultimate model.

Although references to Bābur and Humāyūn are not altogether absent from the Jahāngìr Nāma, they pertain to the literary, naturalist, or bacchanalian traits of these rulers' characters rather than to their statecraft. ${ }^{61}$ On the contrary, Akbar is often portrayed as inspiring, assisting, and legitimizing Jahāngī in his handling of political affairs. In this light, the vivid obituary the latter devotes to his father in the first pages of the memoirs is very remarkable. ${ }^{62}$ Akbar's imprint on his son's government is more particularly evident in the three following spheres: religious policy, administrative practices, and, to a much lesser extent, military expansion. Jahāngīr's presentation of his father's kingdom as a haven of tolerance hardly allows one to doubt his approval of the sulh-i kull ("universal peace") policy inaugurated in the last part of the previous reign. ${ }^{63}$ Similarly, when he bans the slaughter of animals on fixed days of the week or when he pays his first visit to the Hindu ascetic Jadrūp, Jahāngīr models himself even more explicitly on this aspect of his father's religious legacy. ${ }^{64}$ Indeed, a true continuity links the reigns of the father and the son in this domain: despite the concessions made to conservative Muslims, the non-sectarian management of the empire, which had prevailed since the mid 1580s, continued unabated and state pluralism in matters of religious patronage remained the official

59 Jahāngīr, Jahāngīr Nāma: Memoirs of Jahāngīr: 357.

${ }^{60}$ Muțribī-ul-Asamm Samarqandī, Khātirāt-i Muṭibī: Conversations with Emperor Jahāngīr, trans. R. C. Foltz (Costa Mesa: Mazda Publishers, 1998): 22-3, 87.

${ }^{61}$ Jahāngīr, Jahāngīr Nāma: Memoirs of Jahāngīr: 76-7 and 299 for references to the Bābur Nāma and the writings of Humāyūn; 133 on Bābur's depiction of fauna; 76-7 and 83 for the "wine basins" carved in the rock by Bābur and Jahāngīr in the surroundings of Kabul.

${ }^{62}$ Jahāngīr, Jahāngīr Nāma: Memoirs of Jahāngīr: 39-44.

63 Jahāngīr, Jahāngīr Nāma: Memoirs of Jahāngìr: 40.

${ }^{64}$ Jahāngīr, Jahāngīr Nāma: Memoirs of Jahāngīr: 26, 209. 
agenda under Jahāngīr's rule. ${ }^{65}$ It is also well-known that the main principles of Mughal administration, as sketched out by Akbar, underwent no major change at the hands of his successor. At several points in his narrative, Jahāngīr selfappraisingly comments on this stability. ${ }^{66}$ Right from the opening of the memoirs, he also sets himself up as an heir to Akbar's work of military expansion, and singles out the conquest of Transoxiana and Deccan as the main goal of his future policy. ${ }^{67}$ Considering that little was subsequently achieved in the military field, this assertion should, however, rather be seen as some sort of rhetorical device. Although, Jahāngīr succeeded in submitting Rājpūt Mewar, kept the Deccani sultanates under continuous pressure, and initiated the Mughal advance toward the southern and eastern fringes of Bengal, ${ }^{68}$ there is no point in denying the fact that his imperial project differed substantially from the "conquest state" option favored by his father. ${ }^{69}$

In view of Akbar's omnipresence in the memoirs, casting Jahāngīr as the dull successor may be a tempting option, and most historians have actually taken that step. There is, however, one crucial element that this interpretation does not take into account: Jahāngìr himself stood at the very origin of this omnipresence and certainly knew how to make the most of it. Indeed, his self-presentation as the dutiful heir of Akbar allowed him to capture (at least a part of) his father's aura and legitimacy, thereby strengthening his own authority. As those to Chingīz Khān and Tīmūr, Jahāngīr's references to Akbar are thus highly instrumental.

While we have so far examined the main components of Jahāngīr's political horizon, it is now appropriate to turn to his exercise of power and to analyze the values underlying it as well as the instruments through which he implemented it.

${ }^{65}$ For Jahāngīr's patronage of non-Muslim institutions such as the Krishnaite temples of the Braj country or a Shaivaite monastery of north Panjab, see the farmāns presented by T. Mukherjee and I. Habib, "The Mughal Administration and the Temples of Vrindavan during the Reigns of Jahangir and Shah Jahan." Proceedings of the Indian Historical Congress, 49th Session (1989): 287-299 and B. N. Goswamy and J. S. Grewal, eds. The Mughals and the Jogis of Jakhbar: some madad-i ma'ash and other documents (Simla: Indian Institute of Advanced Studies, 1967).

${ }^{66}$ Jahāngīr, Jahāngīr Nāma: Memoirs of Jahāngīr: 64, 148.

67 Jahāngīr, Jahāngīr Nāma: Memoirs of Jahāngīr: 33.

${ }_{68}$ For an eye-witness account of the latter, see Mìrzā Nāthan, Bahāristān-i Ghaibī.

${ }^{69}$ Maximizing Jahāngīr's war achievements does not provide a way out of traditional historiography, as it similarly lays undue emphasis on the military as the touchstone for assessing the "success" or "failure" of any given monarch. 


\section{The Exercise of Power: Values and Instruments}

Jahāngìr attached such importance to the royal dispensation of justice that it was the object of his very first act of government:

After my accession, the first command issued by me was to have a chain of justice (zinjir $r-i$ ' $a d l$ ) hung so that if those charged with administering the courts were slack or negligent in rendering justice to the downtrodden, those who had suffered injustice could have recourse to the chain and pull it so that the sound would cause awareness. ${ }^{70}$

In so doing, Jahāngīr conspicuously followed the model set up by king David and the Sasanid ruler Anūshīrwān (r. 531-579)—two monarchs to whom Muslim authors like al-Tha'labī (d. 1036) or the more famous Seljuq wazìr Niżām-ul-Mulk (d. 1092) alternatively ascribed the paternity of the chain of justice. However, the fact that Jahāngīr never again afterward alludes to the chain suggests that it was rather meant as a symbol than as an effective administrative instrument. The remainder of the memoirs is nonetheless peppered with passages in which the Mughal monarch does not only administer justice to the human subjects of his empire but also to the animals of his kingdom. ${ }^{71} \mathrm{He}$ is also keen on underlining his impartiality, whatever the rank of the people he has to try. However, the duties of the just king were not limited to his acting as a supreme judicial authority: above all he had to ensure the security and prosperity of his subjects. Logically, the protective duty of the monarch applied in the first place to the bodies of his subjects, and this task was partly fulfilled by the royal hunt. In this respect, Jahāngīr's numerous depictions of his heroic slaughter of wild beasts show that he was fully aware of this particular aspect of his cynegetic activities. ${ }^{72}$ The emperor also had to protect his people from human exactions, especially if these were executed by the royal agents he had appointed to carry out this very task. The numerous cases of recall, demotion, or dismissal scattered throughout the Jahāngīr Nâma should (at least partly) be understood in this light: in most of these cases, the disgrace is actually said to have derived from the agents' tyranny over the local population. Finally, the monarch had to protect his people from himself, the exercise of royal prerogatives (such as hunting) being sometimes harmful to his subjects.

70 Jahāngīr, Jahāngīr Nāma: Memoirs of Jahāngīr: 24.

71 See, for example, Jahāngīr, Jahāngīr Nāma: Memoirs of Jahāngīr: 142, 203, 264, 339, $366,396$.

${ }^{72}$ For an in-depth analysis of Mughal hunting, see Ebba Koch, Freer Gallery Occasional Papers, New Series, vol. 1: Dara Shikoh Shooting Nilgais: Hunt and Landscape in Mughal Painting (Washington D. C.: Freer Gallery of Art and Arthur M. Sackler Gallery, Smithsonian Institution, 1998). 
Beyond his basic duty of being a protector, the just king was also expected to establish and guarantee the necessary conditions for his subjects' prosperity and welfare. The absence of tax pressure or, most often, keeping taxation at a reasonable rate were a few of the instruments that allowed the sovereign to fulfil this requirement. Significantly, the proscription of a number of taxes is the object of the first of the twelve decrees Jahāngī promulgated right after his accession; he also took the opportunity provided by his imperial tours to abolish the local imposts he considered archaic. ${ }^{73}$ In the event of a serious crisis, his privileged status - he was, one should remember, the representative of God on earth-allowed him to successfully ask for divine intervention: when a severe drought affected Mandu in the summer of 1617, the monarch thus absorbed himself in prayers and rain soon afterward started to pour down. ${ }^{74}$

Considered to be an obligation for every righteous Muslim, charity was also the last of the duties falling to the just king. Relieving the people in need was indeed a way to make up for the inequalities that inevitably beset every kingdom and, consequently, allowed the monarch to maintain or restore some sort of social equipoise. Jahāngīr's activities in this domain were wide-ranging: royal weighing $(t \bar{u} l \bar{a} d \bar{a} n)^{75}$ or Muslim festivals provided traditional opportunities for charitable acts, and distributing money when entering a city or visiting a shrine was also a common, almost systematic, practice. The monarch was further particularly anxious to meet personally with the deserving people who came to his court and satisfy their needs. Finally, imperial charity took the form of endowments to hospitals or soup-kitchens (ghulurkhāna). ${ }^{76}$

It should by now be clear that Jahāngïr's justice was neither limited to the enforcement of the law nor to religious piety; rather, its purpose was to maintain an equilibrium between the various groups in society (the weak and the strong, the rich and the poor, the diverse religious and ethnic communities of the realm, etc) so as to avoid its lapsing into chaos. As argued by Alam, such a conception of justice derived straight from the above-mentioned $a \underline{k h} l \bar{a} q$ literature and its most eminent representative Nāṣir-ud-dīn Ṭūṣi.

In order to turn this ideal of social harmony into a reality, each member of the society was moreover required to stick to the position he had been assigned to and to refrain from crossing the bounds of his social standing. Not surprisingly, the imperial court was the place where these limits were the most

73 Jahāngīr, Jahāngīr Nāma: Memoirs of Jahāngīr: 26, 45, 76, 378.

74 Jahāngīr, Jahāngīr Nāma: Memoirs of Jahāngīr: 221.

75 This ceremony of Indian origin took place at least twice a year, for the solar and lunar birthdays of the monarch: an amount equal to his weight in gold, silver, and other commodities was then distributed to the poor.

76 Jahāngīr, Jahāngīr Nāma: Memoirs of Jahāngīr: 26, 60. 
conspicuous, especially within the dīwān-i ' $\bar{a} m m-u-\underline{k h} \bar{a} s \underline{\text { s }}$ (hall of public and private audience). In the palace of Agra, Jahāngìr thus proceeded to rigidify the arrangement that had been introduced by Akbar; this was a spatial device which simultaneously singled out the person of the emperor and created a visible hierarchy among his subjects through the erection of a series of physical barriers. As a matter of fact, the monarch systematically ordered the building or renovation of ceremonial structures in the cities he visited that lacked the proper installations. ${ }^{77}$ In a very similar spirit, he also listed the cloths he alone was entitled to wear. $^{78}$ This insistence on staying within the bounds prescribed by one's status was particularly strong in the case of those to whom royal authority had been delegated. In February 1612, Jahāngīr thus promulgated an edict listing twelve imperial prerogatives which the amirs were forbidden to appropriate: with two exceptions, all of them related to matters of etiquette. ${ }^{79}$ Interestingly enough, the list simultaneously shows the nature and extent of the activities set aside for the monarch and suggests that these privileges were not really respected. Although the emperor worked hard to limit the power of his amirs, especially those stationed in the provinces, he did not tolerate any infringement on their authority (an expression of his own), and manșabdārs who contravened this rule were severely rebuked..$^{80}$

In order to implement justice and command respect-the two key principles of Jahāngïr's government as described in his memoirs-three kinds of instruments were at the monarch's disposal: law, force, and symbol, the last two often combining their effects. Even though early modern Islamic rulers were theoretically not entitled to legislate (the $\operatorname{sharl}^{-} a$ supposedly provided them with all they needed in this domain), some of them, especially the Ottomans, were nonetheless active legislators. ${ }^{81}$ They mostly operated in the administrative field through the promulgation of edicts or farāmin (sg. farmān), and Jahāngīr's accession decree as well as his 1612 edict are good examples of such proceedings. When the so-defined rules were broken due to a deliberate transgression,

77 Jahāngīr, Jahāngīr Nāma: Memoirs of Jahāngīr: 83 (Kabul), 145 (Agra), 169 (Mandu), and 244 (Ahmadabad). Except for the case of Mandu on which see Michael Brand, "Mughal Ritual in Pre Mughal Cities: The Case of Jahangir in Mandu." Journal of the Islamic Environmental Design Research Centre 1-2 (1991): 8-17, none of Jahāngīr's architectural adjustments seems to have survived.

78 Jahāngīr, Jahāngīr Nāma: Memoirs of Jahāngīr: 223.

79 Jahāngīr, Jahāngìr Nāma: Memoirs of Jahāngīr: 127-8. For a slightly different version of the edict, see Mìrzā Nāthan, Bahāristān-i Ghaibāa: i: 213-4.

${ }^{80}$ See, for example, Jahāngīr, Jahāngīr Nāma: Memoirs of Jahāngīr: 176, 369.

${ }^{81}$ On this question and the most famous example of Sulaimān Kānūnī (r. 1520-1566), see Halil Inalcik, "Suleiman the Lawgiver and Ottoman Law." Archivum Ottomanicum 1 (1969): 105-138. 
a failure, or an inability to obey, the monarch resorted to what juridical literature and $a \underline{k h l a ̄ q}$ treatises commonly referred to as siyāsat, i.e. the power to punish. ${ }^{82}$ Jahāngīr's response to these transgressions could be concrete or symbolic according to the nature of the offence. From a pragmatic point of view, the imperial answer varied from demotion to torture and from imprisonment to mutilation. Symbolically, the excessive character of some chastisements was meant to imprint fear on the minds of the offender and of the audience, the latter metonymically standing for all the subjects of the realm. This comes out particularly clearly in the case of the supporters of the rebel Prince Khusrau: while his two closest accomplices were put respectively into an ox hide and a donkey's skin before being paraded through the city of Lahore, the bulk of the prince's troops was hanged on both sides of the road leading to the city, so as "to maintain order and discipline in the kingdom." 83 Here as elsewhere, the punishment is a deterrent. Although in this instance the seriousness of the crime accounts for the monarch's wrath, his punishments seem somewhat disproportionate on other occasions, e.g. when Jahāngir sentenced to death a servant who had inopportunely interrupted the royal hunt. ${ }^{84}$ This last example is especially meaningful because it shows that the emperor attached equal importance to the offences that threatened the actual exercise of his power or its ritual dimension. Several passages of the memoirs moreover suggest that Jahāngīr paid particular attention to the nature and enforcement of punishment. As seen above, the monarch did not leave any doubts about the purpose of public chastisement. His reaction to the execution of the Safavid prince Șafì Mìrzā by his father Shāh 'Abbās is also significant: the news apparently came as a shock and prompted him to comment most favorably on his own treatment of his son Khusrau. ${ }^{85}$ According to this and other remarks, Jahāngīr probably considered himself to be a relatively lenient monarch.

To conclude this brief sketch of the business of kingship as seen by Jahāngīr, it is worth elaborating on the contradiction that seemingly exists between the monarch's claimed accessibility — notably through such symbolic acts as the installation of the chain of justice-and the bulk of practices which conversely aroused a feeling of impassable distance between the ruler and his subjects-be it through rigid courtly ceremonials or dramatized public chastisements. However, these two poles of royal behavior should more fruitfully be seen as

82 Siyāsat also had the more general meaning of "politics."

83 Jahāngīr, Jahāngīr Nāma: Memoirs of Jahāngīrr: 58; see 113, and 406 for other similar examples.

${ }^{84}$ Jahāngīr, Jahāngīr Nāma: Memoirs of Jahāngīr: 106.

85 Jahāngīr, Jahānḡ̄r Nāma: Memoirs of Jahāngīr: 178, 201. 
two complementary aspects of the imperial "propaganda" which was aimed at the people of the realm, meaning both subjects and (potential) rebels. Having said so, we should now move on to another hallmark of Jahāngīr's personality as revealed in his memoirs: his naturalistic bent of mind.

\section{NATURALISM AND POWER}

Partly built on a peculiar Mughal tradition, ${ }^{86}$ Jahāngīr's deep interest in natural sciences (biology, botany, geology, mineralogy, and zoology) also strongly echoes the preoccupations of many early modern European rulers such as the Habsburg emperor Rudolf II (d. 1612). ${ }^{87}$ The numerous botanical and zoological observations peppered throughout the memoirs make this interest abundantly clear. In respect of the first domain, the following description (made during a trip in Kashmir in March 1620) is particularly eloquent:

There was one strange flower in particular with an odd shape. It had five or six orangecolored flowers blooming with their heads down (...). There was another flower like the boni, and around it were tiny flowers shaped and colored like jasmine (...). There were also many yellow Judas trees along the road. The flowers of Kashmir are beyond counting or enumeration. Which ones shall I write about? How many can one write about? Only those that are really special can be recorded. ${ }^{88}$

In terms of zoology, the saga of a pair of cranes is by far the most remarkable, Jahāngīr devoting four successive passages to the mating of these birds (which he named Lailá and Majnūn in reference to the lovers of Niżāmī's eponymous romance), the brooding and hatching of their eggs, and their relations with wild cranes.$^{89}$ Finally, his comments on the fall of a meteor near Jalandhar and on the quality of diamonds mined in different places of the empire, as well as the countless questions he asked Mutribī about the exact color of Tìmūr's gravestone in Samarqand, show his interest in mineralogy. ${ }^{90}$ Although the accu-

86 While Bābur wrote extensively on the fauna and flora of India in his memoirs, Akbar had his grand-father's depictions illustrated with paintings, see Dale, The Garden of Eight Paradises: 359-360. For a previous assessment of Jahāngīr's naturalism, see M. A. Alvi and A. Rahman, Jahangir-the Naturalist (Delhi: National Institute of Sciences of India, 1968).

${ }^{87}$ On Rudolf II's naturalism, see the recent contribution by Paula Findlen, "Cabinets, Collecting and Natural Philosophy." In Rudolf II and Prague: The Court and the City, eds. E. Fučíková et al. (London and New York: Prague Castle Administration, Thames \& Hudson, and Skira, 1997): 209-219.

${ }^{88}$ Jahāngīr, Jahāngīr Nāma: Memoirs of Jahāngīr: 327-8.

89 Jahāngīr, Jahāngīr Nāma: Memoirs of Jahāngīr: 266, 269-270, 274, 279.

90 Jahāngīr, Jahāngīr Nāma: Memoirs of Jahāngīr: 362; 268; Samarqandī, Khātịirāt-i Muțribī: Conversations with Emperor Jahāngīr: 22-3 and Muṭribī-ul-Asamm Samarqandī, Khătịāt-i Mutribī, ed. A. G. Mirzoyef (Karachi: Institute of Central \& West Asian Studies, University of Karachi, 1977): 20. 
racy of the monarch's descriptions-which finds its counterpart in the development of realistic portraiture under his rule ${ }^{91}$-lends an indisputable scientific color to the memoirs, the world-view that informed these depictions cannot truly be qualified as such. Jahāngīr's fascination for flora, fauna, or minerals was actually driven by an aesthetic sense which matched beauty (husn) with strangeness: at the core of his curiosity lay the marvels of the Creation known as ' $a j \bar{a}$ ' $i b$ in the medieval Islamic world and as mirabilia in the contemporary Occident. The various collections gathered by the emperor (on which more below) powerfully embodied this particular taste for strangeness.

Jahāngīr's grasp on the world was, however, not restricted to mere observation: his inquisitive mind often resorted to experimentation in order to increase his knowledge, give a natural explanation for strange phenomena, or (in)validate traditional beliefs. The skinning of two sheep and the exposure of their skin at two different places "to see what the difference in the air was" serves as a good illustration of the first point. ${ }^{92}$ As for the experiments carried out on the bodies of a lion and a tiger, he aimed to discover the physical origin of the proverbial bravery of these two species. ${ }^{93}$ Most of the time, however, the goal of Jahāngīr's experiments was to put long-held beliefs to the test. Having rubbed bitumen on a chicken's leg (carefully broken by himself) to no result, he thus invalidated the efficacy that was traditionally ascribed to this substance. ${ }^{94}$ Empirical methods were also used to overcome local superstitions. When confronted in Rawalpindi with the local people's fear of the harmful creatures that supposedly populated a pool, he ordered a sheep, and then one of his servants to be thrown in: as both came out unhurt, he proudly recorded his triumph over the villagers' credulity. ${ }^{95}$ In other instances, experimentation conversely strengthened the belief in quasi-supernatural phenomena. In the course of his stay in north Panjab during the winter of 1622, Jahāngīr put a Hindu renouncer's power of concentration to the test in the following way:

It occurred to me that in a state of drunkenness or unconsciousness some external movement might happen. He [the renouncer] was therefore given several bowls of doubledistilled spirits to drink. He was in such control of himself that he (...) stood just as

91 Apart from the existing paintings, Mutribī's account provides further evidence of Jahāngīr's obsession with faithful representation and accurate detail: the poet was once summoned by the emperor to assess the lifelike character of the portraits of two Central Asian rulers. Mutribī having accordingly pointed out their defects, both portraits were sent to the artist for correction (Samarqandī, Khātirāt-i Mutribī: Conversations with Emperor Jahāngīr: 76-8 and Samarqandī, Khātirīāt-i Muṭribī: 61-2).

92 Jahāngīr, Jahāngīr Nāma: Memoirs of Jahāngīr: 274-5.

93 Jahāngīr, Jahāngīr Nāma: Memoirs of Jahāngìr: 207.

94 Jahāngīr, Jahāngīr Nāma: Memoirs of Jahāngīr: 143-4.

95 Jahāngīr, Jahāngīr Nāma: Memoirs of Jahāngīr: 72. 
rigidly as before until he lost consciousness and was carried away like a corpse. God was merciful that no mortal injury was done to him. ${ }^{96}$

The resistance offered by the ascetic thus forced the emperor to acknowledge the strangeness of his powers. This last case, as well as the Rawalpindi story, or the painting of the dying 'Ināyat Khān, ${ }^{97}$ endow Jahāngïr's naturalism with a kind of morbidity: in these three instances, his curiosity either led him to play with other people's lives or prevailed over his compassion (?) for them. Already breaking through in these passages, the emperor's cruelty elsewhere assumes a much more violent character and may be linked to the quirky aspect of his personality. Probably deriving (at least in part) from his immoderate love for alcohol and opium, Jahāngīr's fickleness was also a creative source from which fascinating and surrealist visions sprang, such as a royal procession which was turned into "an amazing field of flowers." 98

A very interesting corollary of Jahāngīr's relationship with nature was his obsession with measurement. ${ }^{99}$ Most often, if not systematically, he subjected the places he visited to a thorough estimation of their size. Accuracy was the rule in this domain, as is exemplified in the following passage:

In the Akbar Nāma Shaikh Abū'l Fazl has written that the length of the vale of Kashmir (...) is approximately $120 \mathrm{kos}$, and that the width is not less than ten kos or more than twenty-five. As a precautionary measure, and in order to be precise, I ordered a group of reliable experts to measure the length and breadth by ropes so that the actual measurement could be recorded. What Shaikh Abü’l Faẓl wrote as 120 kos actually came out as sixty-seven. ${ }^{100}$

Imperial interest in measurement also applied to the flora, fauna, and minerals of the realm. A strange palm tree was thus measured from every possible angle ${ }^{101}$ and animals were systematically weighed during shooting parties or on other occasions. Similarly, the weight of the precious stones presented to the

96 Jahāngīr, Jahāngīr Nāma: Memoirs of Jahāngīr: 376.

97 Mesmerized by the gauntness of the sick amìr, Jahāngīr ordered the imperial painters to draw his likeness (Jahāngīr, Jahāngīr Nāma: Memoirs of Jahāngīr: 279-281). Both the painting and its sketch have survived; for a reproduction, see Stuart Cary Welch, Peinture impériale moghole (Paris: Éditions du Chêne, 1978).

98 Jahāngīr, Jahāngīr Nāma: Memoirs of Jahāngīr: 72.

99 While this Mughal penchant may be traced back to Bābur's memoirs, see Dale, The Garden of Eight Paradises: 58-60, its most monumental expression was clearly the $\bar{A}^{\prime} \bar{i} n-i$ Akbari - a thorough survey of India commissioned by Akbar and appended by Abū'l Fazl to his Akbar Nāma.

100 Jahāngīr, Jahāngīr Nāma: Memoirs of Jahāngīr: 331. The kos is a measure of distance roughly corresponding to two and half miles.

101 Jahāngīr, Jahāngīr Nāma: Memoirs of Jahāngīr: 208. Its strangeness also accounts for the emperor's commissioning a picture of it, which is today preserved in the Raza Library of Rampur. 
emperor was invariably recorded with great accuracy. Finally, the "surveying monarch" was also keen on taking census. To no surprise, his yearning for numbers was particularly strong in the hunting sphere, as becomes clear from the edifying list he provided the reader with:

From the beginning of my twelfth year, A.H. 988 [1580-81], until the end of the present year (...) [March 1617], 28,532 animals were taken in my presence. Of this total, I shot with my own hand 17,16[7] animals as follows: quadrupeds, 3,203: lion, 86; bear, cheetah, fox, otter, hyena, 9; nilgai, 889; maha, a species of deer as large and bulky as a nilgai, 35; buck and doe antelope, chikara, spotted dear, mountain goat, etc, 1,672; ram and red deer, 215; wolf, 64; wild ox, 36; boar, 90; ibex, 26; mountain ram, 22; [agarli sheep, 32]; wild ass, 6; hare, 23. Birds, 13,964 as follows: pigeon, 10,348; lagarjhagar [fighting] hawk, 3; eagle, 2; kite, 23; jugdh [owl], 39; pelican, 12; mouse-eater, 5; sparrow, 41; dove, 25; büm [owl], 30; duck, goose, heron, etc, 150; crow, 3,473. Aquatic animals: magarmacch , which means crocodile, $10 .{ }^{102}$

Jahāngīr's determination to depict, measure, enumerate-and thereby classify-everything he observed in his kingdom should be interpreted as a powerful statement of his domination: in doing so, he physically and symbolically took possession of his territories and its inhabitants and reasserted his sovereignty over them. This character trait also served as a manifestation of his universal power: just as Solomon's, the monarch's authority did not only extend over human beings but encompassed the whole of Creation. ${ }^{103}$ Jahāngīr's power over the animal world took two principal forms: suppressing the forces which threatened the kingdom's stability and administering justice. That the royal hunt served the first purpose is made abundantly clear by the emperor himself who did not hesitate to take it a step further and portrayed himself as an authentic civilizing hero: "During the felicitous reign of this petitioner at the divine court wildness has been eliminated from the nature of wild beasts to such an extent that lions have become tame and roam in packs among people, without restraints or chains, and they neither harm them or run away." 104 While animals had to show due obedience to their emperor, they also benefited from his boundless equity: Jahāngīr's administering justice to a pair of cranes crying for

102 Jahāngīr, Jahāngīr Nāma: Memoirs of Jahāngīr: 216. Jahāngīr was not alone in his taste for morbid inventories. Between 1571 and 1588, Philip II of Spain (d. 1598) collected 7,422 relics and ordered them to be meticulously catalogued, see Geoffrey Parker, Philip II. 3rd edition (Chicago and La Salle (Ill.): Open Court, 1995): xv. Both cases involved precise counting and classification of dead beings in order to celebrate the way they lived (the saints) or died (the martyrs and the preys). The meaning and role of these collections was, however, very different.

103 On Jahāngìr's strong attraction to the Solomonic tradition of kingship, see Koch, Mughal Art and Imperial Ideology.

104 Jahāngīr, Jahāngīr Nāma: Memoirs of Jahāngīr: 144; see also 218-9. 
their lost babies significantly reminds the reader of a very similar story of a dove appealing to Solomon's help. ${ }^{105}$

Jahāngīr's naturalism as expressed in his memoirs is intrinsically linked to his conception of power and reveals another facet of his grasp on the world he governed: his ability to describe, measure, and organize his kingdom endows him with omniscience and omnipotence. On a more symbolic level, this bent for universalism also informs his taste for collecting and what may be called the museological character of his power.

\section{SEIZING THE WORLD: THE IMPERIAL COLLECTIONS}

Like some of his Muslim predecessors and so many of his European contemporaries, ${ }^{106}$ Jahāngīr cultivated royal collecting to the highest degree, and stands first among the Mughals in this respect. His reign is in any case the most fully documented: apart from the surviving objects, the memoirs and the abovementioned Khātirāt-i Muțribì provide abundant and eloquent information. Far from being a detailed examination of the collections, the present analysis aims at giving a general idea of their content and scope while underlining their political significance. In much the same way as imperial naturalism, these collections were animated by the breath of 'ajab: gathering at his court the marvels of the Creation, the monarch ambitioned to transform the former into a microcosm of the latter, proclaiming by the same token the universality of his power.

In order to reach this aim, Jahāngīr resorted to multiple supplying networks. Regarding objects of European origin, the ports of Cambay (in Gujarat) and of Portuguese Goa played a key role: there, the emperor got in supplies of luxury artefacts and paintings through Muqarrab Khān-one of his most devoted servants who held various assignments in the region between 1607 and 1612 . Safavid Iran functioned as another supply node, as has already been alluded to in the discussion of Shāh 'Abbās's generous giving of Timurid memorabilia to

105 Jahāngīr, Jahāngīr Nāma: Memoirs of Jahāngīr: 203 and Jocelyne Dakhlia, Le divan des rois. Le politique et le religieux dans l'islam (Paris: Aubier, 1998): 332 for the Solomonic anecdote as recorded by al-Ibshīhī.

106 For a recent analysis of the collections gathered by medieval Islamic princes, see Houari Touati, L'armoire à sagesse: Bibliothèques et collections en Islam (Paris: Aubier, 2003). The literature on the royal collections of Renaissance Europe is plethoric; see Oliver Impey and Arthur MacGregor, eds. The Origins of Museums: The Cabinet of Curiosities in Sixteenth- and Seventeenth-Century Europe (Oxford: Clarendon Press, 1985) for a broad survey, and Thomas Da Costa Kaufmann, The Mastery of Nature: Aspects of Art, Science and Humanism in the Renaissance (Princeton, N. J.: Princeton University Press, 1993): 174-194 for a stimulating political interpretation of late sixteenth- and early seventeenth-century Central European collections. 
Jahāngīr. Transoxiana and Naqshbandī Khwājas were still another network through which curiosities poured into the Mughal court. The exchanges took place either directly between the emperor and the khwāja or indirectly through the numerous Naqshbandī ashräf (nobles) settled in India. ${ }^{107}$ Thanks to these varied sources of supply, Jahāngī succeeded in creating a collection which, much like the Kunst- und Wunderkammern of sixteenth- and seventeenth-century Europe, brought together the marvels of nature and the masterpieces of human ingenuity. As shown by the typology of its content, the drive behind it was clearly universal. ${ }^{108}$

Representing the mineral kingdom, Jahāngīr's collection of gems and jades was certainly the most prestigious and the most precious as a commodity: rubies were the most sought-after, followed by diamonds, emeralds, and sapphires. Embodying an illustrious past, "historical stones" were also highly valued: the Ulugh Beg's spinel presented by Shāh 'Abbās or the Jamkura diamond sent by Ibrahīm 'Ādil Shāh II of Bijapur (r. 1580-1627) may be cited as famous examples. Regarding the jades, special mention should be made of a nephrite tankard inscribed with Ulugh Beg's name and which was presented to Jahāngīr by the manșabdār Mūnis. ${ }^{109}$

Natural curiosities or mirabilia made up a second category including elephant and narwhal tusks, bezoar stones, a gigantic sugarloaf, ${ }^{110}$ and a fragment of a meteor which the monarch transformed in the following way:

I ordered Master Dā'ūd to make a sword, dagger, and knife of it (...). He mixed three parts of the 'lightning' iron with one part of other iron and produced two swords and one dagger he showed me. (...) I named one of them shamshīr-i qätiti (cutting sword) and the other barqsirisht (lightning-essence). Bebadal Khān composed and presented the following quatrain for the occasion: "The world attained order from the world-seizing monarch [shāh-i jahāngīr], / And during his reign raw iron fell from lightning. / From that iron was made by his world-conquering order / A dagger and a knife and two swords." 111

The case of the meteor is especially significant because it reveals the motivations underlying the act of collecting. The desire to appropriate, implying both the transformation and the naming of the object, is here evident and shows

107 Jahāngīr, Jahāngīr Nāma: Memoirs of Jahāngīr: 182, 262, 343; Samarqandī, Khātịāt-i Mutribì: Conversations with Emperor Jahängīr: 40-1, 73.

108 The following classification has, to a degree, been inspired by Yves Porter, "Regalia and Exotica: Notes on the Imperial Collections of the Great Mughals." Paper presented at the International Workshop, "Patronage in Indo-Persian Culture", 21-23 March 2001.

109 Jahāngīr, Jahāngīr Nāma: Memoirs of Jahāngīr: 95-6.

110 Jahāngīr, Jahāngīr Nāma: Memoirs of Jahāngīr: 243-4, 343; 193, 306-7; 144; Samarqandī, Khātitiātei Mutribìi: Conversations with Emperor Jahāngīr: 39.

111 Jahāngìr, Jahāngīr Näma: Memoirs of Jahāngìr: 362-3. Of the three artefacts mentioned here, only the knife has survived to this day (Freer Gallery of Art, Smithsonian Institution. Purchase F55.27). 
that the regnal name chosen by the monarch, far from being restricted to the symbolic sphere, was intended to translate his relation to the universe: Jahāngīr was indeed a world-seizer. In this respect, the royal collection was at once a means and an expression of the monarch's universal grasp.

Embodying the animal kingdom, the imperial menagerie may be seen as a third type of collection. Besides countless elephants and horses, it also included animals prized for their rarity or novelty. It thus housed a whole range of albino specimens, a North American turkey, an Abyssinian zebra, and a Sri Lankan orang-utan. ${ }^{112}$ As shown by numerous miniatures, these animals were meant to be exhibited, but many of them were also used for a variety of activities: war, hunting, imperial ceremonies, fighting shows, or observations and experiments. Finally, the vegetal kingdom was represented through the paintings commissioned by the monarch: illustrating a wide range of species, they combined to form a sumptuous pictorial herbarium. During Jahāngīr's reign, the artist Manșūr was recognized as the undisputed master of naturalist painting for both his wildlife and floral miniatures. ${ }^{113}$

Rich in naturalia, the imperial collection was equally, if not more, well provided with artificialia. For the sake of analysis, the latter may be further divided into two categories: the exotica, on the one hand, and the manuscripts and paintings of the imperial library on the other. Contrary to what could have been expected from Jahāngīr's obsession with measurement, the monarch does not appear to have taken any particular interest in scientific instruments. The only reference to such an object concerns an astrolabe of Ulugh Beg which Jahāngīr requested from his "brother" Shāh 'Abbās, but it was probably coveted much more for its dynastic significance than for its scientific value. ${ }^{114}$ Although the Mughal's naturalist collection certainly functioned-like its European counterparts - as a laboratory for testing contemporary knowledge about the natural world, it obviously lacked the scientific paraphernalia which were another hallmark of the latter.

As suggested by their designation, the exotica included objects of exotic (i.e., non-indigenous) origin, among which Chinese porcelains ${ }^{115}$ and European artefacts figured the most prominently. In this respect, Mutribī's account gives eloquent evidence of the wonder generated by the introduction at the Mughal court

112 Jahāngīr, Jahāngīr Nāma: Memoirs of Jahāngīr: 92-3, 262; 133; 360; 94.

113 On his work, see Som Prakash Verma, Mughal Painter of Flora and Fauna Ustād Manșūr (Delhi: Abhinav Publications, 1999).

${ }_{114}$ Riazul Islam, A Calendar of Documents on Indo-Persian Relations (1500-1750). 2 vols. (Tehran and Karachi: Iranian Culture Foundation \& Institute of Central \& West Asian Studies, 1979-1982): i: 183 (J. 74).

115 Jahāngīr, Jahāngīr Nāma: Memoirs of Jahāngīr: 89, 193; Asok Kumar Das, "Chinese Porcelains at the Mughal Court." Silk Road Art and Archeology 2 (1991-1992): 383-409. 
of such European novelties as the pencil and the eraser. ${ }^{116}$ Besides the frequent mention in the memoirs of luxury wares of European craftsmanship (gold and silver vessels, Venetian crystal chests, cups, swords, etc), ${ }^{117}$ the paintings commissioned by Jahāngīr point to his taste for Western-styled clocks and regalia. ${ }^{118}$ The emperor's fondness for things European was, however, nowhere stronger than in the domain of pictorial art. Originating after the encounter with the European prints and paintings brought to Akbar's court by the first Jesuit missionaries, this interest kept growing under Jahāngīr who did not hesitate to adorn some of the rooms of his palaces with Christian figures and portraits of Western rulers. ${ }^{119}$ To no surprise, Western, especially Jesuit, texts focus the most extensively on this particular subject, but a number of Mughal paintings, the content of the imperial muraqqa's (albums), and some surviving fragments of mural paintings also confirm Jahāngīr's enthusiasm for European art. ${ }^{120}$

Books, whether or not illustrated, and calligraphic specimens formed another category of artefacts particularly prized by the emperor. According to the account of the Dutch Joannes De Laet, the imperial library (kitäbkhāna) already held no less than 24,000 volumes at the death of Akbar in 1605, and the Jahāngìr Nāma and the monumental inventory made by John Seyller show that the royal collection increased significantly under his successor. ${ }^{121}$ Manuscripts of non-Mughal origin accounted for approximately $42 \%$ of the library contents: 24,5\% came from the Iranian world, 8,5\% from Central Asia, and 3\% from the Sultanates of pre-Mughal India; the origin of the last $6 \%$ has not yet been identified. ${ }^{122}$ Books entered the library in a variety of ways (purchase, booty, escheat property), the presents given to the monarch playing a substantial role. ${ }^{123}$ Thanks to the tremendous work done by John Seyller, Jahāngīr's attitude toward books is now better known. He was indeed the first Mughal dynast to

116 Samarqandī, Khāțirāt-i Mutribī: 22-3 and Samarqandī, Khāțirāt-i Muṭribì: Conversations with Emperor Jahāngīr : 26-7.

117 Jahāngīr, Jahāngīr Nāma: Memoirs of Jahāngīr: 108, 174, 186, 318.

118 See, for instance, Jahāngīr Preferring a Shaikh to Kings (ca. 1615-8) for a baroque hourglass-throne and Jahāngīr Triumphing over Poverty (ca. 1625) for a crown of Western inspiration. For reproductions, see Jahāngīr, Jahāngīr Nāma: Memoirs of Jahāngīr: 257 and 25.

119 Guerreiro, Jahangir and the Jesuits: 63-7 (Agra); Roe, The Embassy of Sir Thomas Roe: i: 240 (Ajmer); Foster, Early Travels in India: 163 (Lahore).

${ }^{120}$ The literature on this question is abundant. See, inter alia, Milo Cleveland Beach, "The Gulshan Album and Its European Sources." Bulletin of the Museum of Fine Arts, Boston 63/332 (1965): 62-91, Bailey, "The Indian Conquest of Catholic Art": 24-30, Koch, Mughal Art and Imperial Idelogy, and Franke, Akbar und Ğahāngīr.

121 John Seyller, "The Inspection and Valuation of the Manuscripts in the Imperial Mughal Library." Artibus Asiae 57/3-4 (1997): 243-349.

${ }^{122}$ Porter, "Regalia and Exotica", relying on the inventory by Seller, "The Inspection".

123 See, for example, Jahāngīr, Jahāngīr Nāma: Memoirs of Jahāngīr: 108, 299, 378. 
write methodical notations of ownership in the books that came into his possession. Through this practice, which was both continued and systematized by Shāh Jahān, Jahāngīr asserted his identity and pride as a collector. Of the 255 manuscripts listed by John Seyller, thirty-nine bear autograph inscriptions of the monarch, and these call for a number of remarks.

First, more than half of them pertain to non-Mughal manuscripts. Moreover, whereas the monarch readily boasts of his connoisseurship of painting in his memoirs, ${ }^{124}$ his actual comments on illustrated manuscripts rarely allude to their miniatures: of five such inscriptions, only two go beyond the mere mention and offer some kind of stylistic assessment. The latter are nonetheless very interesting because they highlight the imperial practice of manuscript refurbishing. The addition of folios or paintings, the adorning or embellishment of borders, the repainting of extant miniatures, all were meant to make up for what were regarded as the three major defects of a manuscript: the bad condition of the book, the archaic style of its paintings, or the loss of the political utility of its iconography. ${ }^{125}$ This practice may be traced back to the 1570 s, but really gained momentum during Jahāngīr's reign — a fact that comes as another powerful illustration of the emperor's determination to appropriate and transform the universe. Jahāngīr's inscriptions commenting on painting are rather scarce, but a good quarter of them includes an appreciation of the calligraphy of the book and gives the name of the calligrapher. Far from being surprising, the emperor's preference for calligraphy over painting may be explained by the greater prestige traditionally enjoyed by the former art in the Islamic world. What is, however, especially significant is the dissonance, in this and other cases, between what Jahāngīr says in his memoirs, on the one hand, and in his inscriptions, on the other. ${ }^{126}$ Acting as a useful reminder of the critical distance required when dealing with autobiographies, these observations are mostly interesting for their delineation of the emperor's literary tastes. Sa'dī, Jāmī, and Hāfiż seem to have been Jahāngīr's favorite authors. Their works were undoubtedly among the Persian classics every Mughal prince was supposed to know, but Jāmī's close connection with the Timurids also probably accounts for Jahāngīr's special interest in him: like the painter Bihzād or the calligrapher Sultạn 'Alī Mashhadī, Jāmì was one of the prominent figures in the reign of the last Timurid ruler of

124 Jahāngīr, Jahānḡ̄r Nāma: Memoirs of Jahāngīr: 99-100, 268, 319.

125 John Seyller, "Recycled Images: Overpainting in Early Mughal Art." In Humayun's Garden Party: Princes of the House of Timur and Early Mughal Painting, ed. S. Canby (Bombay: Marg Publications, 1994): 50-80.

126 For other examples, compare Jahāngīr, Jahāngīr Nāma: Memoirs of Jahāngīr: 275 and 108 with Seyller, "The Inspection": 253-4 and 269. 
Herat, Sultān Husain Baiqarā. That the emperor valued over all other books a Khamsa by 'Alī Shir Nawā'̄ - a great poet and close friend of the sultanwritten in the hand of Sultān 'Alī Mashhadì and illustrated in Herat should thus come as no surprise. He thereby adhered to a tradition that originated in the days of his great-grandfather: from Bābur's time onward, the Mughals took to collecting the manuscripts and paintings produced at the behest of their illustrious ancestors. ${ }^{127}$ Strangely enough, this dynastic connection was never emphasized by Jahāngīr in his inscriptions.

As said at the beginning of this essay, this is not the place to deal at length with the paintings commissioned by the emperor during his reign or with the political discourse he formulated through them. There is, however, one question that should be addressed by way of conclusion: the ordering and collecting of images meant for the illustration of the Jahāngìr Näma. Several passages of the memoirs suggest that the monarch conceived of them as an illustrated book, and most of his textual references to painting pertain to the commissioning of pictures for his own work. Unfortunately, no original version of the illustrated Jahāngīr Näma has survived to this day, and that such a version was ever completed in the lifetime of the monarch is still open to question. By comparing textual references and extant paintings, we may, however, be able to reconstruct the original iconography of the memoirs, as can be seen in the work done by Milo Cleveland Beach who was also the first scholar to provide a thorough analysis of this pictorial undertaking. ${ }^{128}$ According to this art historian, the iconography of the Jahaingìr Näma had a lot in common with contemporary muraqqa's: besides naturalistic vignettes of the Mughal kingdom or individual portraits, the illustrations include paintings of the major events of the reign, shooting parties and court life, as well as scenes emphasizing Jahāngīr's closeness with major religious figures of the empire; finally, a number of images depict the monarch's generosity. Despite the wide variety of the themes chosen for illustration, the majority of the paintings focus on the emperor's public life, two moments of the latter being more particularly stressed: the darbār or audience, which functioned as a shrine for the visibility and centrality of the king's person and proclaimed the superiority of his status over his subjects; and the homage paid by the monarch to holy places or saintly figures, the connection thereby created endowing him with the necessary spiritual legitimacy. All in all, the illustrations of the memoirs offered the reader-viewer powerful images of Jahāngīr's mundane domination

127 Lentz and Lowry, Timur and the Princely Vision: 321.

128 Milo Cleveland Beach, "Jahāngīr's Jahāngīr-Nāma." In The Powers of Art: Patronage in Indian Culture, ed. B. S. Miller (Delhi: Oxford University Press, 1992): 224-234. 
and of his privileged bond with the divine. The latter aspect was further reinforced by a new pictorial treatment of the royal figure: whereas Akbar's painters emphasized his human character and stressed his constant immersion into action, Jahāngir remained far from the ordinary, which is signalled by the radiant nimbus that henceforth adorned the face of the Mughal pādshāh. ${ }^{129}$

What the emperor exactly had in mind when commissioning paintings for his own memoirs, is moreover made very clear through his description of the curiosities presented by Muqarrab Khān in March 1612:

He had brought several very strange and unusual animals (bisyār gharīb wa 'ajīb) I had not seen before. No one even knew what their names were. Although His Majesty Firdaus-Makānī [Bābur] wrote in his memoirs of the shapes and forms (șurāt wa ashkāl) of some animals, apparently he did not order the artists to depict them. Since these animals looked extremely strange to me, I both wrote of them and ordered the artists to draw their likeness in the Jahāngìr Näma so that the astonishment (sairat) one has at hearing of them would increase by seeing them. ${ }^{130}$

This last sentence does not only show that the monarch had developed a profound insight into the use of images, but also specifies the role they were supposed to play within the memoirs: following the Aristotelian concept of the "inner senses" which argues for the superiority of sight over hearing, images were here meant to reinforce the effect of the language. ${ }^{131}$ Commenting on what he perceived as "lacks" in his ancestor's approach, Jahāngīr skilfully highlighted his own achievements, and this with good reason. Although the writing of memoirs by (Islamic) rulers was far from being an uncommon practice in the early modern world, the illustration of the Jahängìr Näma at the monarch's behest certainly lent a unique and original character to this text.

129 The nimbus provided a visual translation of the illuminist theory of sovereignty favored by Akbar in the later part of his reign. One may further note that although the halo was depicted with some restraint in the illustrations of the memoirs, it literally invaded the space of Jahāngīr's allegorical portraits. See, most significantly, Jahāngīr Preferring a Shaikh to Kings and Jahāngīr embracing Shāh 'Abbās (ca. 1618) reproduced in Jahāngīr, Jahāngīr Nāma: Memoirs of Jahāngìr: 257 and frontispiece.

130 Jahāngīr, Jahāngīr Nāma: Memoirs of Jahāngīr: 133; Jahāngīr, Tūzuk-i Jahāngīrī: 105; and Jahāngīr, Jahāngìr Nāma: Tūzuk-i Jahāngīrī: 123.

131 Interestingly, this same argument was developed by the sixteenth-century European naturalists who first introduced woodcuts of plant or animal specimens in their treatises, see Pamela H. Smith and Paula Findlen, "Commerce and the Representation of Nature in Art and Science." In Merchants and Marvels: Commerce, Science, and Art in Early Modern Europe, eds. P. H. Smith and P. Findlen (New York: Routledge, 2002): 8, as well as by the Jesuits to justify their use of images, see Gauvin Alexander Bailey, "The Truth-Showing Mirror: Jesuit Catechism and the Arts in Mughal India." In The Jesuits: Culture, Sciences and the Arts 1540-1773, eds. O’Malley, et al. (Toronto: University of Toronto Press, 2000): 388. 
That Jahāngìr-through his memoirs and the other media he used to publicize his imperial program - actually succeeded in legitimizing and sustaining his rule is moreover made clear by the recorded reaction of the Mughal elite. As mentioned at the beginning of this article, this reaction may be inferred from, on the one hand, the examination of a number of texts composed or patronized by the military and administrative dignitaries of the realm, the so-called umara $\vec{a}$. Significantly enough, these texts (chronicles, instructions for princes, historical poems, etc) bear no trace of ideological opposition to the Mughal domination; they rather testify to the strength of the imperial model. They also illuminate the political traditions peculiar to these individuals and the solutions they crafted in order to justify their cooperation. Furthermore, it is worth pointing out that Jahāngīr, unlike Akbar, did not have to face major rebellions from the ranks of the nobility — with the partial exception of Mahābat Khān's uprising; ${ }^{132}$ during the first quarter of the seventeenth century, the only revolts that formed a threat to his imperial authority actually originated from the Mughal princely sphere and were intimately connected with the absence of a fixed law of succession. Jahāngīr's success was, however, relative: ideological adhesion did not imply total submission to the rules of administration and, while the nobility eschewed open confrontation, its members took advantage of the weaknesses of the state apparatus to increase their powers in the province. From the time of Akbar onward, the imperial process of centralization had to face the relentless opposition of the umara $\vec{a}^{3}$. The members of the religious elite, on the other hand, seem to have responded rather positively to Jahāngīr's discourse and policy. The monarch's pragmatism and flexibility enabled him to meet the challenge of contemporary politico-religious pressures, and thus to regain the lost confidence of orthodox Muslims: the fact that two treatises of government were dedicated to him by 'ulama $\bar{a}$ ' unmistakably denotes a changed atmosphere. Although some 'ulama $\bar{a}$ ' and Sufis persevered in their opposition to the non-sectarian management of the empire and called for a restoration of the legal inferiority of the non-Muslims, none of them challenged Jahāngīr's legitimacy to rule or the quasi-divine status to which, concluding the process initiated by Akbar, he had elevated the emperors of the House of Tìmūr. True, Jahāngīr was not the founding father of canonical Mughal ideology, but he certainly has to be given credit for being one of its master-craftsmen. Combining literary and iconographic

132 During the spring of 1626, Mahābat Khān took the royal court, including Jahāngīr, hostage. A weapon in the hands of Prince Parwìz, the amīr planned to hold the emperor captive until the latter's death so as to facilitate Parwiz's accession to the throne; the prince's demise in the following autumn logically put an end to the project. 
processes, his memoirs undeniably stand as a masterpiece of Late Renaissance imperial propaganda.

\section{BIBLIOGRAPHY}

Aigle, Denise. 2004. Le grand Jasaq de Gengis-Khan, l'Empire, la culture mongole et la sharī'a. Journal of the Economic and Social History of the Orient 47/1: 31-79.

Akimushkin, Oleg et al., eds. 1996. The St. Petersburg Muraqqa': Album of Indian and Persian Miniatures from the 16th through the 18th Century and Specimens of Calligraphy by Imād al-Hasanī. Milan: ARCH Foundation \& Lugano and Leonardo Arte srl.

Alam, Muzaffar. 2000. Akhlāqi Norms of Mughal Governance. In The Making of IndoPersian Culture: Indian and French Studies, eds. M. Alam, F. N. Delvoye and M. Gaborieau. Delhi: Manohar: 67-95.

- 2001. The Crisis of Empire in Mughal North India: Awadh and the Punjab, 1707-1748. Reprint. Delhi: Oxford University Press.

Alvi, M. A. and A. Rahman. 1968. Jahangir-the Naturalist. Delhi: National Institute of Sciences of India.

Alvi, Sajida Sultana. 1989. Religion and State during the Reign of the Mughal Emperor Jahangir (1605-1627). Studia Islamica 79: 95-119.

Anooshahr, Ali. 2006. Disclaiming Tamerlane's Inheritance and the Rise of the Mughal Empire. Paper presented at the Clark Library conference, "Imperial Models and the 'Translatio Imperii': Rethinking the Early Modern World," 3-4 November 2006.

Bailey, Gauvin Alexander. 1998. The Indian Conquest of Catholic Art: The Mughals, the Jesuits and Imperial Mural Painting. Art Journal 57/1: 24-30.

—. 2000. The Truth-Showing Mirror: Jesuit Catechism and the Arts in Mughal India. In The Jesuits: Culture, Sciences and the Arts 1540-1773, eds. O'Malley et al. Toronto: University of Toronto Press: 380-401.

Balabanlilar, Lisa. 2007. Lords of the Auspicious Conjunction: Turco-Mongol Imperial Identity on the Subcontinent. Journal of World History 18/1: 1-39.

Bāqir Khān, Muhammad (Najm-i Șānī). 1989. Mau'iża-i Jahāngīrī. Advice on the Art of Governance: An Indo-Islamic Mirror for Princes of Muhammad Bāqir Najm-i Sānī, ed. and trans. S. S. Alvi. Albany: State University of New York Press.

Beach, Milo Cleveland. 1965. The Gulshan Album and Its European Sources. Bulletin of the Museum of Fine Arts, Boston 63/332: 62-91.

—. 1992. Jahāngīr's Jahāngīr-Nāma. In The Powers of Art: Patronage in Indian Culture, ed. B. S. Miller. Delhi: Oxford University Press: 224-234.

Brand, Michael. 1991. Mughal Ritual in Pre Mughal Cities: The Case of Jahangir in Mandu. Journal of the Islamic Environmental Design Research Centre 1-2: 8-17.

Dakhlia, Jocelyne. 1998. Le divan des rois. Le politique et le religieux dans l'islam. Paris: Aubier.

Dale, Stephen F. 2004. The Garden of Eight Paradises: Bäbur and the Culture of Empire in Central Asia, Afghanistan and India (1483-1530). Leiden: E. J. Brill.

Darling, Linda T. 2002. "Do Justice, Do Justice, For that is Paradise": Middle Eastern Advice for Indian Muslim Rulers. Comparative Studies of South Asia, Africa and the Middle East 22/1-2: 3-19.

Das, Asok Kumar. 1991-1992. Chinese Porcelains at the Mughal Court. Silk Road Art and Archeology 2: 383-409.

Della Valle, Pietro. 1991. The Travels of Pietro Della Valle in India from the Old English Translation of 1664 by G. Havers, edited with a life of the author and introduction and notes by Edward Grey. 2 Vols. Reprint. Delhi: Asian Educational Services. 
Elliot, Henry Miers and John Dowson, eds. 2001. The History of India as Told by its Own Historians. 8 Vols. Reprint. Delhi: Low Price Publications.

Ettinghausen, Richard. 1961. The Emperor's Choice. In De Artibus Opuscula XL: Essays in Honor of Erwin Panofsky, ed. M. Meiss. New York: New York University Press: 98-120.

Faruqui, Munis Daniyal. 2002. Princes and Power in the Mughal Empire, 1569-1657. PhD. Duke University.

Findlen, Paula. 1997. Cabinets, Collecting and Natural Philosophy. In Rudolf II and Prague: The Court and the City, eds. E. Fučíková et al. London and New York: Prague Castle Administration, Thames \& Hudson, and Skira: 209-219.

Findly, Ellison Banks. 1993. Nur Jahan: Empress of Mughal India. Delhi: Oxford University Press.

Flores, Jorge. 2004. Two Portuguese Visions of Jahangir's India: Jerónimo Xavier and Manuel Godinho de Erédia. In Goa and the Great Mughal, eds. J. Flores and N. V. e Silva. Lisbon: Calouste Gulbenkian Foundation \& Scala Publishers: 44-67.

Foster, William, ed. 1999. Early Travels in India, 1583-1619. Reprint. Delhi: Low Price Publications.

Franke, Heike. 2005. Akbar und ĞGhāngīr: Untersuchungen zur politischen und religiösen Legitimation in Text und Bild. Schenefeld: EB-Verlag.

Goswamy, B. N. and J. S. Grewal, eds. 1967. The Mughals and the Jogis of Jakhbar: some madad-i macash and other documents. Simla: Indian Institute of Advanced Studies.

Guerreiro, Ferñao. 1997. Jahangir and the Jesuits, trans. C. H. Payne. Reprint. Delhi: Munshiram Manoharlal.

Habib, Irfan. 1969. The Family of Nur Jahan during Jahangir's Reign: A Political Study. In Medieval India-A Miscellany. Bombay: Asia Publishing House. Vol. 1: 74-95.

- 1997. Timur in the Political Tradition and Historiography of Mughal India. In Cahiers d'Asie centrale, vols. 3-4: L'héritage timouride, Iran-Asie centrale-Inde, XV ${ }^{e}-X V I I I^{e}$ siècles, dir. M. Szuppe. Tashkent and Aix-en-Provence: Édisud: 297-312.

Haidar, Mansura. 1992. The Yasai Chingizi (Tura) in the Medieval Indian Sources. In Mongolia: Culture, Economy and Politics (Indian-Mongolian Assessment), eds. S. Bira et al. Delhi: Khama Publishers: 53-66.

Hasan, S. Nurul. 1959. The Theory of Nur Jahan Junta-A Critical Examination. Proceedings of the Indian History Congress, 21st Session: 324-335.

Husain, Afzal. 1999. The Nobility under Akbar and Jahāngīr: A Study of Family Groups. Delhi: Manohar.

Impey, Oliver and Arthur MacGregor, eds. 1985. The Origins of Museums: The Cabinet of Curiosities in Sixteenth- and Seventeenth-Century Europe. Oxford: Clarendon Press.

Inalcik, Halil. 1969. Suleiman the Lawgiver and Ottoman Law. Archivum Ottomanicum 1: 105-138.

Islam, Riazul. 1979-1982. A Calendar of Documents on Indo-Persian Relations (1500-1750). 2 Vols. Tehran and Karachi: Iranian Culture Foundation \& Institute of Central \& West Asian Studies.

Jahāngīr. 1864. Tūzuk-i Jahāngīrī, ed. S. A. Khan. Ghazipur and Aligarh.

—. 1980. Jahāngīr Nāma: Tūzuk-i Jahāngīrī, ed. M. Hashim. Tehran: Intishārāt-i Bunyād-i Farhang-i Irān.

—. 1999. Jahāngīr Nāma: Memoirs of Jahāngīr, Emperor of India, trans. W. M. Thackston. Washington D. C. and New York: Freer Gallery of Art and Arthur M. Sackler Gallery, Smithsonian Institution \& Oxford University Press.

Kāmgār Husainī, Ghairat Khān (Khwāja). 1978. Ma’āsirir-i Jahāngīrī, ed. A. Alavi. Bombay: Asia Publishing House.

Kaufmann, Thomas Da Costa. 1993. The Mastery of Nature: Aspects of Art, Science and Humanism in the Renaissance. Princeton, N. J.: Princeton University Press.

Khāfī Khān. 1983. Muntakhab-ul-lubāb, ed. K. Ahmad. 3 Vols. Reprint. Osnabrück: Biblio Verlag. 
Khan, Iqtidar Alam. 2000. Akbar's Personality Traits and World Outlook-A Critical Reappraisal. In Akbar and his India, ed. I. Habib. Reprint. Delhi: Oxford University Press: 79-96.

Koch, Ebba. 1998. Freer Gallery Occasional Papers, New Series, vol. 1: Dara Shikoh Shooting Nilgais: Hunt and Landscape in Mughal Painting. Washington D. C.: Freer Gallery of Art and Arthur M. Sackler Gallery, Smithsonian Institution.

—. 2001. Mughal Art and Imperial Ideology: Collected Essays. Delhi: Oxford University Press.

Lāhaurī, 'Abd-us-Sattār b. Qāsim. 2006. Majālis-i Jahāngīrī, eds. A. Naushāhī and M. Niżāmī. Tehran: Mīrās-i Maktub.

Lefèvre, Corinne. Forthcoming. Pouvoir et élites dans l'Empire moghol de Jahāngīr (r. 16051627). Paris: Les Indes Savantes.

Lentz, Thomas W. and Glenn D. Lowry. 1989. Timur and the Princely Vision: Persian Art and Culture in the 15th century. Los Angeles: Los Angeles County Museum of Art.

Mìrzā Nāthan. 1936. Bahāristān-i Ghaibū: A History of the Mughal Wars in Assam, Cooch Behar, Bengal, Bihar and Orissa during the reigns of Jahāngīr and Shāh Jahān by Mìrzā Nāthan, trans. M. I. Borah. 2 Vols. Gauhati: Government of Assam.

Mukherjee, T. and I. Habib. 1989. The Mughal Administration and the Temples of Vrindavan during the Reigns of Jahangir and Shah Jahan. Proceedings of the Indian Historical Congress, 49th Session: 287-299.

Mu'tamad Khān, Muhammad Sharīf. 1982. Iqbāl Nāma-i Jahāngīrī, eds. M. Abdullah and A. Ali. Reprint. Osnabrück: Biblio Verlag.

Parker, Geoffrey. 1995. Philip II. 3rd edition. Chicago and La Salle (Ill.): Open Court.

Pelsaert, Francisco. 1957. A Contemporary Dutch Chronicle of Mughal India, trans. B. Narain, ed. S. R. Sharma. Calcutta: Susil Gupta (India) Ltd.

Porter, Yves. 2001. Regalia and Exotica: Notes on the Imperial Collections of the Great Mughals. Paper presented at the International Workshop, "Patronage in Indo-Persian Culture," 21-23 March 2001.

Prasad, Beni. 1922. History of Jahangir. London: Oxford University Press.

Quinn, Sholeh A. 2000. Historical Writing During the Reign of Shah 'Abbas: Ideology, Imitation, and Legitimacy in Safavid Chronicles. Salt Lake City: University of Utah Press.

Richards, John F. 1978. The Formulation of Imperial Authority under Akbar and Jahangir. In Kingship and Authority in South Asia, ed. J. F. Richards. Madison: South Asian Studies, University of Wisconsin: 252-285.

Rizvi, Saiyid Athar Abbas. 2002. A History of Sufism in India. Vol. 2: From Sixteenth Century to Modern Century. Reprint. Delhi: Munshiram Manoharlal.

Roe, Thomas. 1899. The Embassy of Sir Thomas Roe to India, 1615-1619, as Narrated in his Journal and Correspondence, ed. W. Foster. 2 Vols. London: Hakluyt Society.

Samarqandī, Muṭribī-ul-Asamm. 1977. Khātịāat-i Mutribī, ed. A. G. Mirzoyef. Karachi: Institute of Central \& West Asian Studies (University of Karachi).

—. 1998. Khātịāât-i Mutribī: Conversations with Emperor Jahāngīr, trans. R. C. Foltz. Costa Mesa: Mazda Publishers.

Seyller, John. 1994. Recycled Images: Overpainting in Early Mughal Art. In Humayun's Garden Party: Princes of the House of Timur and Early Mughal Painting, ed. S. Canby. Bombay: Marg Publications: 50-80.

- 1997. The Inspection and Valuation of the Manuscripts in the Imperial Mughal Library. Artibus Asiae 57/3-4: 243-349.

Skelton, Robert. 1988. Imperial Symbolism in Mughal Painting. In Content and Context of Visual Arts in the Islamic World, ed. P. Soucek. London and University Park: Pennsylvania State University Press: 177-187.

Smith, Pamela H. and Paula Findlen. 2002. Commerce and the Representation of Nature in Art and Science. In Merchants and Marvels: Commerce, Science, and Art in Early Modern Europe, eds. P. H. Smith and P. Findlen. New York: Routledge: 1-25. 
Subrahmanyam, Sanjay. 1992. Iranians Abroad: Intra-Asian Elite Migration and Early Modern State Formation. Journal of Asian Studies 51/2: 340-363.

—. 2002. Frank Submissions: The Company and the Mughals between Sir Thomas Roe and Sir William Norris. In The Worlds of the East India Company, eds. H. Bowen and N. Rigby. Woodbridge: The Boydell Press: 69-96.

—. 2005. Explorations in Connected History. 2 Vols. Delhi: Oxford University Press.

Terry, Edward. 1777. A Voyage to East-India. Reprint. London.

Tirmizi, Sayyid Akbarali Ibrahimali. 1989. Mughal Documents (1526-1627). Delhi: Manohar.

Touati, Houari. 2003. L'armoire à sagesse: Bibliothèques et collections en Islam. Paris: Aubier.

Verma, Som Prakash. 1999. Mughal Painter of Flora and Fauna Ustād Manșūr. Delhi: Abhinav Publications.

Welch, Anthony and Stuart Cary Welch. 1982. Arts of the Islamic Book: The Collection of Prince Sadruddin Aga Khan. Ithaca and London: Cornell University Press.

Welch, Stuart Cary. 1978. Peinture impériale moghole. Paris: Éditions du Chêne. 